\title{
UNIWERSYTET STEFANA BATOREGO W WILNIE W LATACH 1929-1939 WE WSPOMNIENIACH JANA WILCZYŃSKIEGO
}

\author{
Przemysław Marcin ŻUKOWSKI (Uniwersytet Jagielloński, Kraków) \\ ORCID: 0000-0002-8584-3917
}

\section{WPROWADZENIE}

Londyński Instytut Józefa Piłsudskiego przechowuje m.in. kolekcję Bohdana Podoskiego, polityka II Rzeczypospolitej i działacza emigracyjnego, ale również absolwenta Wydziału Prawa i Nauk Społecznych Uniwersytetu Stefana Batorego w Wilnie (USB). Znajduje się w niej chociażby mowa wygłoszona na pogrzebie Zygmunta Jundziłła, prawnika, polityka, zastępcy profesora prawa cywilnego USB. Czytamy w niej, iż mało kto mógł Jundziłłowi dorównać w znajomości prawa cywilnego. „Pielęgnował w swojej duszy wizję Rzeczypospolitej Obojga Narodów, ideę jagiellońską, i miał w głębi tej duszy żal, że Rzeczypospolita odrodziła się bez pogoni w herbie"". W 2019 roku, zarówno w Republice Litewskiej, jak i w Rzeczypospolitej Polskiej, obchodziliśmy rocznicę założenia Uniwersytetu w Wilnie. Ogólną, 440. — powołania do życia uczelni w 1579 roku przez króla polskiego i Wielkiego Księcia Litewskiego Stefana Batorego, oraz szczegółową, 100. rocznicę wskrzeszenia przez Naczelnego Wodza Wojsk Polskich Józefa Piłsudskiego w 1919 roku. Rocznica ta — co może być li tylko trywialnym stwierdzeniem — zachęca do spojrzenia na dzieje tej uczelni w szerszym kontekście, pozbawionym narodowych, partykularnych interesów. Być może ta perspektywa spowoduje, że banalność uroczystości wspomnieniowych natchnie nas wszystkich uczonych, ale i patrzących nadal na Wilno z sentymentem — do głębszego myślenia o dziedzictwie tej Wszechnicy Batorowej. I mam tu przede wszystkim na myśl króla

\footnotetext{
${ }^{1}$ Instytut Józefa Piłsudskiego w Londynie (dalej: IJP), Kolekcja 107 B. Podoskiego, teczka 12, Mowa na pogrzebie Z. Jundziłła.
} 
fundatora, a nie nazwę, jaką w latach 1919-1939 ten Uniwersytet nosił. Niemniej przywołać można tutaj wspomnienia Wacława Lednickiego, kiedy ten - jeszcze jako młody człowiek - rozmawiał ze swoim ojcem o wyborze kierunku studiów. Aleksander Lednicki, polityk i adwokat, na propozycję swojego syna, że będzie studiował filologię, odpowiedział: „A więc jeśli filologia - to znaczy: profesura. Tak, profesorem możesz być wszędzie, nawet i w Moskwie, ale najlepiej w Krakowie. Polak może być profesorem uniwersytetu w Moskwie czy Petersburgu - nauka jest uniwersalna"2. Na zasadzie takiej właśnie uniwersalności, ale i wielowiekowej łączności „obojga narodów”, Polski i Litwy, również dostrzega się nie tylko osiągnięcia USB, ale i ich trwałośc. Przecież nie można dyskutować o dziejach prawa sądowego litewskiego, pomijając prace Stefana Ehrenkreutza czy Seweryna Wysłoucha, historii dawnego Wielkiego Księstwa bez analizowania dorobku Stanisława Kościałkowskiego, Henryka Lowmiańskiego czy Ryszarda Mienickiego. Nie wspominając już o najbardziej „uniwersalnych” czy „umiędzynarodowionych” dyscyplinach, jak nauki ścisłe czy medyczne.

Prezentowany czytelnikom materiał źródłowy dotyczy przede wszystkim dziejów polskiej nauki i polskiego USB, aczkolwiek żywię nadzieję, iż odnajdą się w nim również i te - zasygnalizowane wyżej - pierwiastki uniwersalności nauki i tradycji dawnej jagiellońskiej unii. Autorem wspomnień dotyczących drugiego dziesięciolecia działalności USB — z lat 1929-1939 - jest Jan Zygmunt Wilczyński. Pora przybliżyć jego sylwetkę. A postać ta jest niemal tak samo ciekawa (dorobek, lub jego brak, podróże naukowe, praca akademicka $w$ różnych krajach europejskich i azjatyckich), jak i kontrowersyjna (działalność na pograniczu prawa, etyki i moralności).

Urodził się 8 lutego starego stylu (21 lutego nowego stylu) ${ }^{3} 1891$ r. we wsi Zakrenicze znajdującej się wówczas w guberni kijowskiej Imperium Rosyjskiego. Ojciec, Marian, był dyrektorem Towarzystwa Wzajemnej Asekuracji w Kijowie. Matką uczonego była Franciszka z domu Kochan. Uczęszczał do I Gimnazjum w Kijowie, w którym uzyskał atestat dojrzałości (maturę) w 1908 roku. Następnie wpisał się na Wydział Fizyko-Matematyczny Uniwersytetu w Petersburgu i w latach akademickich 1908/19091910/1911 (semestr pierwszy) był studentem zwyczajnym sekcji przyrodniczej. Uczęszczał na zajęcia m.in. z biologii ogólnej do Władimira Szymkiewicza, zoologii bezkręgowców do Władimira Szewiakowa. W 1910 roku wziął udział w ekspedycji naukowej, gdzie ,[...] zwiedził i poczynił zbiory w Turcji, Grecji, Egipcie i Palestynie”. Na semestr letni roku akademickiego 1910/1911 udał się, dzięki poparciu Władimira Szewiakowa i subwencji z uczelni, na studia na Wydział Filozoficzny Uniwersytetu w Heidelbergu. Tam poświęcił się tematyce biologii bezkręgowców oraz biologii ogólnej, słuchając wykładów m.in. Otto Bütschliego. Na rok 1911/12 powrócił do Petersburga i w 1912 roku otrzymał kandydaturę nauk przyrodniczych (dyplom I stopnia). Trzeba tutaj zauważyć - typowy dla uczonych tamtych czasów, a niekoniecznie dla nas, współczesnych - życiorys, w którym przeplatają się podróże na studia i prace badawcze do różnych ośrodków uniwersyteckich (akademickich) nie tylko w jednym kraju, ale też i na kilku kontynentach. Jan Wilczyński wpisałby się z powodzeniem w dzisiejsze dążenie do umiędzynarodowienia polskiej nauki. To, że państwa polskiego nie było wówczas na mapie politycznej Europy, nie miało przy tych peregrynacjach niemal żad-

\footnotetext{
${ }^{2}$ W. Lednicki, Pamiętniki, t. 1, Toruń 2019, s. 650-651.

${ }^{3}$ Błąd w datacji. Mógł to być 21 lutego (9 lutego starego stylu) lub 20 lutego (8 lutego starego stylu).
} 
nego znaczenia. W tym samym 1912 roku Jan Wilczyński został wysłany dzięki Cesarskiemu Towarzystwu Badania Przyrody do Murmańska, gdzie wykonał pracę dotyczącą fizjologii wydzielania u gwiazdnic ${ }^{4}$. Stała się ona później — o czym niżej — podstawą uzyskania doktoratu filozofii w zakresie botaniki w Uniwersytecie Jagiellońskim w Krakowie (UJ).

Właśnie na semestr letni roku akademickiego 1912/1913 immatrykulował się jako słuchacz zwyczajny na Wydziale Filozoficznym UJ. Zapisał się na zajęcia z zakresu biologii do Michała Siedleckiego (,Zoologia ogólna i systematyczna”) oraz Emila Godlewskiego jun. („Embriologia ogólna” i „Biologia ogólna”). Wybrał poza tym dziś byśmy powiedzieli: spoza kanonu - lektorat z języka włoskiego dla początkujących prowadzony przez ks. Fortunato Gianiniego oraz anatomię szczegółową dróg nerwowych Adama Bochenka wykładającego ten przedmiot na Wydziale Lekarskim. Wykład Tadeusza Garbowskiego o Henryku Bergsonie i jego metafizyce wykreślił $\mathrm{z}$ listy wybranych przedmiotów. Jan Wilczyński obrał, to wiemy na pewno, drogę prowadzącą przez zaliczenie studiów w Rosji i Niemczech i uzupełnienie ich wysłuchaniem semestru w Krakowie, do podjęcia starań o uzyskanie stopnia doktorskiego. Przeszedł, rzec by można, utartą drogą. Podobną pokonał chociażby Wacław Lednicki, który po uzyskaniu stopnia kandydata nauk w zakresie filologii romańskiej i germańskiej w Uniwersytecie Moskiewskim, wysłuchał dwóch semestrów jako student zwyczajny w UJ w roku akademickim 1910/1911 i po przedstawieniu rozprawy i złożeniu egzaminów ścisłych uzyskał doktorat $\mathrm{z}$ filozofii w zakresie filologii romańskiej 12 czerwca 1922 r. w UJ ${ }^{5}$. Wróćmy do Jana Wilczyńskiego. I tak, po spełnieniu przed chwilą wskazanych warunków, złożeniu formalnego podania na ręce dziekana i przedłożeniu rozprawy: O funkcji wydzielniczej jelita tylnego u rodziny Sipunculidae (ogłoszona drukiem w „Rozprawach Akademii Umiejętności”, t. 53, Kraków 1913), która zyskała pozytywne oceny Michała Siedleckiego i Henryka Hoyera jun., został dopuszczony do egzaminów ścisłych. Pierwsze rygorozum, dwugodzinne, z przedmiotu głównego (botanika) oraz pobocznego (fizyka) złożył 27 maja1914 r., a drugie, jednogodzinne, z filozofii ścisłej 25 czerwca 1914 r. i otrzymał 26 czerwca 1914 r. promocję na doktora filozofii w zakresie botaniki. Aktu promocji dokonał — w obecności rektora Kazimierza Kostaneckiego i dziekana Jana Łosia - Michał Siedlecki ${ }^{6}$. Informacja podawana przez samego Jana Wilczyńskiego, że po uzyskaniu doktoratu został asystentem w zakładzie kierowanym przez Michała Siedleckiego, nie znajduje potwierdzenia w źródłach. Zapewne była to ,asystentura” nieformalna, bez umowy i wynagrodzenia.

\footnotetext{
${ }^{4}$ Lietuvos Centrinis Valstybès Archyvas w Wilnie (dalej: LCVA), f. 175, op. 1(I)Bb, spr. 63, Teczka personalna J. Wilczyńskiego, curriculim vitae (brak daty), k. 3.

${ }_{5}$ Archiwum Uniwersytetu Jagiellońskiego w Krakowie (dalej: AUJ), WF II 504, Teczka doktorska W. Lednickiego. Por. P. Flin, E. Panko, Stopnie naukowe w carskiej Rosji, Prace Komisji Historii Nauki PAU 2015 t. XIV, s. 269 i n. Zbiór najważniejszych przepisów uniwersyteckich, oprac. K. W. Kumaniecki, Kraków 1913.

${ }^{6} \mathrm{Na}$ podaniu o dopuszczenie do egzaminów ścisłych podał zoologię jako przedmiot główny i anatomię porównawczą jako poboczny. Por. AUJ, WF II 371, Katalog wydziałowy (dla dziekana) studentów; WF II 504, Teczka doktorska J. Wilczyńskiego; WF II 508, Album Doctorum Philosophiae; S II 244A, Katalog główny (dla kwestury) studentów; S II 516, Album Universitatis Jagellonicae Cracoviensis; S II 521, Liber promotionum Universitatis Jagellonicae. Por. M. Barcik, A. Cieślak, P. Gaszyński, D. Grodowska-Kulińska, U. Perkowska, P. M. Żukowski, Corpus Studiosorum Universitatis Iagellonicae 1850/51-1917/18, t. 3: T-Ż, red. K. Stopka, Kraków 2015.
} 
Od 1913 roku odbywał naukowe podróże zagraniczne w celu prowadzenia badań. Było to możliwe dzięki subsydiom Akademii Umiejętności w Krakowie oraz Kasy Mianowskiego z Warszawy. Udał się m.in. do Triestu i Neapolu. Po wybuchu „Wielkiej Wojny" znalazł się na terenie Imperium Rosyjskiego, gdzie w Uniwersytecie Petersburskim (Piotrogrodzkim) pracował naukowo w latach 1915-1916, m.in. pod okiem Walentina Dogiela. Prowadził zajęcia również na kursach Aleksandra Czerniajewa. Następnie, w latach 1917/1918-1918/1919, wykładał biologię ogólną i zoologię jako docent w Polskim Kolegium Uniwersyteckim w Kijowie. W 1919 roku Jan Wilczyński powrócił do Polski i jednocześnie w Krakowie podjął starania o uzyskanie habilitacji, a w reaktywowanym USB przystąpił do współorganizacji Zakładu Biologii, którym kierował - urlopowany z UJ — jeden z krakowskich mistrzów naszego bohatera, Michał Siedlecki ${ }^{7}$.

Na ręce dziekana Wydziału Filozoficznego UJ przedłożył 28 czerwca 1919 roku podanie o udzielenie venia legendi (prawa wykładania) w zakresie zoologii i tytułu docenta. Podstawą była rozprawa: „Amblyplana tetracladea miri n. sp. Nowy gatunek wirków lądowych ze środkowej Afryki i kilka uwag teoretycznych o filogenetycznem pochodzeniu triclada" oraz szereg innych drobnych rozpraw. Dziekan Tadeusz Sinko przedstawił ją do oceny Michałowi Siedleckiemu i Henrykowi Hoyerowi jun. Referat, podpisany wspólnie, był gotowy 10 marca 1920 roku. Z prawdopodobieństwem graniczącym z pewnością możemy stwierdzić, że referentem głównym był Henryk Hoyer jun., a koreferentem Michał Siedlecki. Niemniej konkluzja referatu była pozytywna i Jan Wilczyński został dopuszczony do drugiego stadium habilitacji. Było nim kolokwium, które odbyło się 26 marca 1920 roku i zostało przyjęte jednomyślnie jako wystarczające. Trzecie stadium habilitacji, wykład, zostało wyznaczone na 29 marca 1920 roku. Tematem wykładu była „rola wydzielania w całokształcie funkcji organizmu” (temat zgłoszony pod numerem 1.; pozostałe to: 2 . „Podstawy systematyki i filogenezy wirusów” oraz 3. „Trawienie i wydalanie u Sipunculidae”) i po jego wygłoszeniu „uznano wykład za wystarczający do habilitacji z zoologji”. Kolegium Profesorów Wydziału Filozoficznego nadało prawo wykładania i tytuł docenta zoologii UJ 16 kwietna 1920 roku. MWRiOP zatwierdziło ją już 27 maja 1920 roku, dodając, iż rozprawę autor musi wydrukować w ciągu roku od daty zatwierdzenia ministerialnego ${ }^{8}$. Ten warunek Jan Wilczyński spełnił dzięki Polskiej Akademii Umiejętności w Krakowie (PAU), gdzie w „Rozprawach Wydziału Matematyczno-Przyrodniczego" opublikował Nowy gatunek wirka lądowego ze środkowej Afryki Amblyplana tetracladea n. sp. (Kraków 1920).

Jan Wilczyński od 1 września 1919 roku zatrudniony został jako starszy asystent w Zakładzie Zoologii na Wydziale Matematyczno-Przyrodniczym (tymczasowo połączonym z Wydziałem Lekarskim) USB. Michał Siedlecki, który był wówczas profesorem na zwyczajnej katedrze zoologii i kierownikiem Zakładu, pełnił przez dwie kadencje w latach akademickich 1919/1920-1920/1921 — funkcję rektora USB i w związku z tym wiele prac dotyczących organizacji Zakładu pozostawił w gestii Jana Wilczyńskiego, za co ten złożył mu serdeczne podziękowania m.in. w drukowanych wspomnieniach. Nota-

${ }^{7}$ M. Siedlecki, Wspomnienia z pierwszych dwóch lat organizacji Uniwersytetu Wieleńskiego, [w:] Księga pamiatkowa ku uczczeniu CCCL rocznicy powstania $i$ wskrzeszenia Uniwersytetu Wileńskiego, t. 2, Wilno 1929, s. 59 i n.

${ }^{8}$ AUJ, WF II 121, Teczka habilitacyjna. Por. U. Perkowska, Corpus Academicorum Facultatis Philosophiae Universitatis Iagellonicae 1850-1945, Kraków 2007; J. Róziewicz, L. Zasztowt, Polskie Kolegium Uniwersyteckie w Kijowie (1917-1919), „Rozprawy z Dziejów Oświaty”, R. 34 (1991). 
bene Jan Wilczyński przyjechał do Wilna razem z Michałem Siedleckim i „,małą gromadką" uczonych, którzy około 20 sierpnia 1919 roku wyruszyli z Warszawy do Wilna9 .

Po ewakuacji z Wilna, w wyniku działań wojennych, w 1920 roku Jan Wilczyński służył w Wojsku Polskim jako ochotnik i uczestniczył w wojnie polsko-bolszewickiej, m.in. jako lotnik-obserwator w 9 eskadrze lotniczej ${ }^{10}$.

Na rok akademicki 1920/1921 (od 1 stycznia 1921 roku) Jan Wilczyński został powołany do wykładów zoologii i biologii ogólnej na Wydziale Lekarskim USB jako zastępca profesora $\mathrm{i}$ był opłacany $\mathrm{z}$ budżetu nieobsadzonej nadzwyczajnej katedry biologii ogólnej. Umowa była odnawiana każdorazowo na kolejne lata akademickie: 1921/1922-1924/1925. Tutaj można podjąć rozważania na temat posiadania — lub nie - przez Jana Wilczyńskiego prawa wykładania. Fakt, ministerialny warunek dotyczący druku rozprawy habilitacyjnej został spełniony. Natomiast prawo wykładania związane było z fakultetem, na którym zostało udzielone. Zatem Jan Wilczyński mógł wykładać jako docent jedynie w Krakowie. Na pewno nie składał w UJ podań o urlop od tzw. „wykładów docenckich”. Nie przeniósł również prawa wykładania na Wydział Matematyczno-Przyrodniczy lub Wydział Lekarski USB. Zatem możemy stwierdzić może nie ze stuprocentową pewnością - że prawo wykładania $\mathrm{w}$ zakresie biologii i tytuł docenta dla Jana Wilczyńskiego wygasł z mocy prawa, gdyż ten nie wygłaszał wykładów na wydziale, na którym je otrzymał. A w Wilnie wykładał na podstawie odnawianych umów na stanowisku zastępcy profesora ${ }^{11}$. Jednocześnie Jan Wilczyński był kierownikiem Zakładu Biologii przy tej katedrze. Tymczasowo również, do czasu przyjazdu do Wilna Jana Prüffera (jego nominacja nosi datę 1 listopada 1921 roku), kierował również Zakładem Zoologii. Z ramienia wileńskiego Uniwersytetu został skierowany do Niemiec, Włoch i Francji w celu pozyskania przyrządów i pomocy naukowych dla swojego Zakładu. Przy okazji tej podróży odwiedził Berlin, Jenę, Heidelberg i Paryż, gdzie zwiedzał zakłady biologiczne. Zdobytą wiedzę i doświadczenie mógł po powrocie spożytkować w Wilnie.

Wraz ze względnym unormowaniem się sytuacji politycznej i wojskowej na ziemi wileńskiej trwały nieprzerwane zabiegi o ściągnięcie do USB na stałe kadry naukowej, w tym obsadzenia - zapisanej w budżecie, a wakującej — nadzwyczajnej katedry biologii ogólnej. Dziekan Wydziału Lekarskiego Ernest Maydell formalnie 12 grudnia 1921 roku rozesłał tzw. ankietę profesorską w sprawie wskazania kandydata lub kandydatów najodpowiedniejszych do powołania na stanowisko profesora $\mathrm{i}$ jednocześnie poprosił o opinię o Janie Wilczyńskim, pracującym już w Wilnie, jako kandydacie może nie najodpowiedniejszym, lecz już wykładającym w USB i w związku z tym mającym największe szanse na objęcie katedry. Na ręce dziekana spłynęły odpowiedzi od Michała Siedleckiego i Emila Godlewskiego jun. z Krakowa, Rudolfa Weigla ze Lwowa oraz Romana Nitcha z Warszawy.

Emil Godlewski jun. obszernie odpisał 28 grudnia 1921 roku. Stwierdził mianowicie, że stałe obsadzenie katedry odbywa się w jak najmniej korzystnych warunkach,

\footnotetext{
${ }^{9}$ M. Siedlecki, Wspomnienia, s. 59 i n.

${ }^{10}$ LCVA, f. 175, op. 1(I)Bb, spr. 63, Teczka personalna J. Wilczyńskiego, curriculim vitae (brak daty), k. 3.

${ }^{11}$ Ustawa z 13 lipca 1920 r. o szkołach akademickich, DzURP 1920, nr 72, poz. 494; J. Jastrzębski, Habilitacja w państwowym szkolnictwie akademickim II Rzeczypospolitej, Analecta. Studia i Materiały z Dziejów Nauki 2010 z. 1-2, s. 63 i n; M. Przeniosło, Stopnie, tytuly i stanowiska naukowe w II Rzeczypospolitej, Res Historica 2012 z. 33, s. 160 i n.; K. Wojtczak, O stopniach naukowych $i$ veniam legendi w II Rzeczypospolitej (część I), Studia Prawa Publicznego $2014 \mathrm{nr} 3$, s. 31 i n.
} 
jeżeli chodzi o powołanie na nią Jana Wilczyńskiego. Wynika to z tego, że poza pracą organizacyjną i dydaktyczną, która pochłonęła Jana Wilczyńskiego niemal przez dwa pierwsze lata pobytu w Wilnie (częściowo była o tym mowa wyżej), od czasów „Wielkiej Wojny" - konstatował dalej Emil Godlewski jun. — nie ogłosił on żadnej poważnej rozprawy naukowej. Uczony proponował odłożyć na czas do dwóch lat stałe obsadzenie katedry, powołać na nią w charakterze zastępcy profesora Jana Wilczyńskiego i umożliwić mu pracę naukową. Zwłaszcza że kilka jego rozpraw jest $\mathrm{w}$ druku, m.in. w PAU. Niemniej Wydział Lekarski ma prawo do podjęcia kroków w kierunku stałego obsadzenia katedry. Wówczas Emil Godlewski jun. proponował również wzięcie pod uwagę następujących uczonych (zachowana oryginalna kolejność $\mathrm{z}$ ankiety): docenta Stanisława Kopcia z Puław oraz doktorów Stanisława Przyłęckiego z Warszawy, Laury Kaufmanówny z Puław oraz Jana Dembowskiego z Warszawy. Emil Godlewski jun. dodał jeszcze:

Jeżeli prócz wyrażenia mojej opinji wolnoby mi było jako dawnemu reprezentantowi tej katedry w Wilnie moją wypowiedzieć radę, to oświadczyłbym się za pierwszą alternatywą z najkategoryczniejszem zastrzeżeniem, że nominacja nastąpi: 1/ po ogłoszeniu dwóch prac Dra Wilczyńskiego, które w Akademji są w druku, 2/ po ogłoszeniu nowo w Wilnie samodzielnie zrobionej poważnej nowej pracy ${ }^{12}$.

Podobną opinię wyraził Michał Siedlecki w piśmie przesłanym do Wilna 29 grudnia 1921 roku. Nie szczędził przy tym pozytywnych słów o pracach organizacyjnych Jana Wilczyńskiego. Wskazał jednak również, że z ostateczną nominacją na katedrę należy się wstrzymać do czasu powiększenia dorobku, gdyż „działalność naukowa p. Dra Wilczyńskiego nie jest bardzo wybitna". Michał Siedlecki wskazał, że de facto Jan Wilczyński jest autorem trzech rozpraw; pierwsza to dysertacja doktorska, druga rozprawa habilitacyjna, a trzecia jest dopiero $\mathrm{w}$ druku ${ }^{13}$. Rudolf Weigl napisał m.in., że prace naukowe Jana Wilczyńskiego, które „[...] cechuje również znaczna rozmaitość tematów, a przedewszystkim jego dotychczasowa działalność nauczycielska, dają mu pożądane kwalifikacje". Roman Nitch przyłączył się do opinii Emila Godlewskiego jun. Do wymienionych wyżej nazwisk kandydatów dopisać należy jeszcze dr Marię Krahelską-Tołwińską, którą zaproponował Roman Nitch ${ }^{14}$. Ostatecznie komisja - po przeanalizowaniu wszystkich odpowiedzi - przychyliła się do opinii krakowskich uczonych i w swoim referacie z 9 września (?) 1922 roku zawnioskowała jak w przytoczonej opinii Emila Godlewskiego jun. Krakowski uczony dodał jeszcze, co nie zostało powyżej przeze mnie przytoczone, ale znalazło uznanie komisji, aby wyjednać dla Jan Wilczyńskiego płacę $\mathrm{w}$ wysokości przewidzianej dla profesora nadzwyczajnego, co znacznie ułatwiłoby mu pracę naukową. Rada Wydziału Lekarskiego na posiedzeniu 23 września 1922 roku przychyliła się całkowicie do wniosku komisji $1^{15}$.

Ostatecznie wniosek nominacyjny dla Jana Wilczyńskiego na nadzwyczajną katedrę uchwaliła Rada Wydziału Lekarskiego USB 28 października 1924 roku. Był to punkt szósty czwartego zwyczajnego posiedzenia Rady, który tutaj przytoczę w całości:

6. Sprawa wyboru prof. Biologii. Kandydat na to stanowisko Dr. Wilczyński

${ }^{12}$ LCVA, f. 175, op. 1(I)Bb, spr. 63, Teczka personalna J. Wilczyńskiego, opinia E. Godlewskiego jun. z 21 grudnia $1921 \mathrm{r}$.

${ }^{13}$ LCVA, f. 175, op. 1(I)A, spr. 101, Wydział Lekarski, opinia M. Siedleckiego z 29 grudnia $1921 \mathrm{r}$.

${ }^{14}$ LCVA, f. 175, op. 1(I)A, spr. 101, Wydział Lekarski, opinia R. Nitscha.

${ }^{15}$ LCVA, f. 175, op. 3(IX)B, spr. 182, Protokoły posiedzeń Rady Wydziału Lekarskiego, protokół z 23 września 1922 r. 
Przed rozpoczęciem sprawy prof. Alexandrowicz złożył następujące oświadczenia: „,nigdy pomiędzy nim a p. Janem Wilczyńskim żadnej sprawy honorowej nie było, a jedynie w roku 1922 postawił p. Wilczyńskiemu wniesione do protokółu rady zarzuty z powodu rachunków z dokonanych zakupów zagranicznych”. Po złożeniu tego oświadczenia prof. Alexandrowicz wyszedł.

Dziekan zarządził tajne głosowanie i do skrutynjum zaprosił prof. Karaffę-Korbutta, K. Michejdę. Na 18 głosujących, uprawionych do głosowania, Dr Wilczyński otrzymał 12 głosów za, 3 głosy przeciw, 3 kartki puste. Wobec powyższego p. Dr Wilczyński został wybrany profesorem nadzwycz[ajnym] Biologii U.S.B. i rada postanowiła wystąpić $z$ tem przez Senat do Ministerstwa ${ }^{16}$.

Senat Akademicki poparł powyższą uchwałę 14 listopada 1924 roku. Prezydent Rzeczypospolitej mianował Jana Wilczyńskiego 17 marca 1925 roku na nadzwyczajną katedrę biologii ogólnej na Wydziale Lekarskim USB w charakterze profesora ${ }^{17}$.

Poza pracą naukową Jan Wilczyński miał co najmniej dwa, pomijając honorowy spór z Jerzym Alexandrowiczem, dochodzenia dyscyplinarne w latach 1927-1928 oraz w latach 1929-1930. W tym ostatnim przypadku była to skarga Jana Bowkiewicza, który zarzucał Janowi Wilczyńskiemu, że ten z przyczyn osobistych nie zgadza się na jego współpracę z Komitetem Badań Jezior Trockich ${ }^{18}$. Po latach, kiedy Jan Wilczyński nie pracował już w USB, Jan Bowkiewicz chciał przenieść swoje prawo wykładania ze Szkoły Głównej Gospodarstwa Wiejskiego w Warszawie na Wydział MatematycznoPrzyrodniczy USB. Dziekan Wydziału Matematyczno-Przyrodniczego Stefan Kempisty 16 grudnia 1937 roku odpisał kandydatowi, że nie widzi możliwości pozytywnego załatwienia sprawy, i poprosił o wycofanie podania. Powodem nieprzychylności Rady miał być dawny zatarg pomiędzy wspomnianymi uczonymi. Jan Bowkiewicz nie ustawał w swoich działaniach i odpisał 17 grudnia, że liczy na sumienność członków Rady, i poprosił o nadanie swojemu podaniu biegu urzędowego. Wyjaśnił też pokrótce sprawy zatargu, który miał miejsce w roku akademickim 1928/1929. Rada na posiedzeniu 15 lutego 1938 roku odmówiła prośbie petenta ${ }^{19}$.

Formalne zatrudnienie Jana Wilczyńskiego w USB zostało zakończone na podstawie rozporządzenia Ministra Wyznań Religijnych i Oświecenia Publicznego Janusza Jędrzejewicza z 25 września 1933 roku, kiedy to katedra biologii na Wydziale Lekarskim USB została zwinięta. Sam Jan Wilczyński przeniesiony został w stan nieczynny z dniem 30 września 1933 roku. Na podstawie postanowienia Prezydenta Rzeczypo-

${ }^{16}$ LCVA, f. 175, op. 3(IX)B, spr. 184, Protokoły posiedzeń Rady Wydziału Lekarskiego, protokół z 28 października 1924 r. Zarzuty, o jakich mowa, zostały postawione przez Jerzego Alexandrowicza na posiedzeniu Rady 13 maja 1922 r., a ich tekst stanowi załącznik do protokołu posiedzenia. Por. LCVA, f. 175, op. 3(IX)B, spr. 181, Protokoły posiedzeń Rady Wydziału Lekarskiego, protokół z 13 maja 1922 r. Odniósł się do nich B. Żongołłowicz w swoich Dziennikach...: „Wilczyński, który wydał pieniądze zakładowe na remont własnego mieszkania w r. 1919/20, uchylił się od sądu honorowego z Aleksandrowiczem, usunął żonę z dwojgiem dzieci i ożenił się ze swoją asystentką, napisał książkę o »dobrych obyczajach« akademickich, zaś półgłówek jakiś w »słowie« grafomańską elukubrację drugiego półgłówka pochwalił. Druga wileńska sanacja uniwersytecka". Por. B. Żongołłowicz, Dzienniki 1930-1936, oprac. D. Zamojska, Warszawa 2004, s. 437.

${ }^{17}$ LCVA, f. 175, op. 14, spr. 630. Teczka personalna J. Wilczyńskiego, pismo S. Grabskiego z 3 kwietnia $1925 \mathrm{r}$.

${ }^{18}$ LCVA, f. 175, op. 1(I)Bb, spr. 63, Teczka personalna J. Wilczyńskiego, liczne pisma, dokumenty, protokoły komisji dyscyplinarnych.

${ }_{19}$ P. M. Żukowski, Słownik docentów Uniwersytetu Stefana Batorego $w$ Wilnie $w$ latach 1919-1939 (w przygotowaniu). 
spolitej z 17 października 1934 roku, z dniem 30 września 1934 roku został zwolniony ze służby państwowej. Jako emerytowany profesor zgłosił na rok akademicki 1935/1936 propozycję wykładów, gdyż jego zdaniem, nie utracił prawa wykładania jako docent. O tym wątku z życiorysu naszego bohatera była już mowa wyżej. Dodatkowo wniósł pod koniec 1935 roku skargę do Najwyższego Trybunału Administracyjnego na ministerialną decyzję przenoszącą go w stan spoczynkư ${ }^{20}$.

Jan Wilczyński nie przerwał pracy naukowej. I tak od 1 kwietnia 1936 roku do 15 grudnia 1937 roku przebywał jako stypendysta MWRiOP w Anglii. Po wybuchu drugiej wojny światowej początkowo był bez zajęcia od 1 grudnia 1939 roku do 1 września 1940 roku. $Z$ nowym rokiem szkolnym otrzymał posadę jako nauczyciel matematyki i biologii w gimnazjach wileńskich, m.in. w III Gimnazjum. Był nim od 1 września 1940 roku do 1 lipca 1941 roku. Następnie pozostał ponownie bez formalnego zatrudnienia od 1 lipca 1941 roku do końca lutego 1942 roku. Wówczas to, z dniem 1 marca 1942 roku, został inspektorem ogrodnictwa na Okręg Wileński Izby Rolniczej. Na tym stanowisku pozostał do 30 września 1943 roku. Ponownie bez pracy był w okresie od 1 października do 30 listopada 1943 roku. Następnie przeniósł się do Warszawy, aby w latach 1943-1944/1945 wykładać na tajnych kompletach Uniwersytetu Warszawskiego i Uniwersytetu Ziem Zachodnich. Po upadku powstania warszawskiego w 1944 roku ewakuowano go do Krakowa ${ }^{21}$.

Po zakończeniu działań wojennych został zaproszony do objęcia wykładów od 1 lutego 1945 roku w Uniwersytecie Poznańskim. W dniu 14 lipca 1945 roku został powołany na delegata Ministra Oświaty do uruchomienia uniwersytetu w Toruniu. Był nim formalnie do 31 sierpnia 1945 roku. Wynikało to z tego, że w dniu 13 sierpnia 1945 r. Ludwik Kolankowski został mianowany przez Ministra Oświaty Czesława Wycecha organizatorem Uniwersytetu Mikołaja Kopernika (UMK), jako delegat ministra $\mathrm{z}$ kompetencjami rektora - z jednoczesnym odwołaniem Jana Wilczyńskiego ${ }^{22}$.

Nominację na profesora zwyczajnego biologii ogólnej na Wydziale Matematyczno-Przyrodniczym otrzymał 1 grudnia 1945 roku (1 maja 1946 roku — dekret Prezydenta KRN). Według zachowanych opinii Jan Wilczyński nie przykładał się do swoich obowiązków profesorskich w Toruniu. Dowiadujemy się tego m.in. z pisma dziekana Wydziału Matematyczno-Przyrodniczego Jana Prüffera do rektora UMK z 8 sierpnia 1947 roku. W latach 1945-1950 Jan Wilczyński był kierownikiem Katedry Biologii Ogólnej z Hydrobiologią na Wydziale Matematyczno-Przyrodniczym. W grudniu 1946 roku została powołana Fundacja Jana i Kazimiery Wilczyńskich przyznająca nagrody za prace naukowe powstałe w UMK. Do 30 kwietnia 1951 roku otrzymał płatny urlop dla

${ }^{20}$ LCVA, f. 175, op. 1(I)Bb, spr. 63, Teczka personalna J. Wilczyńskiego; f. 175, op. 14, spr. 630, Teczka personalna J. Wilczyńskiego.

${ }^{21}$ Archiwum Uniwersytetu Mikołaja Kopernika w Toruniu (dalej: AUMK), sygn. K-1/335, Teczka personalna J. Wilczyńskiego, karta indywidualna z 10 stycznia 1946 r., pismo J. Wilczyńskiego z 23 stycznia 1948 r., zeznanie A. Sniatyckiego z 15 grudnia 1949 r., zeznanie W. Iwanowskiej z 17 grudnia 1949 r., ankieta personalna z 13 czerwca $1950 \mathrm{r}$.

${ }^{22}$ AUMK, K-8/102, Teczka personalna L. Kolankowskiego, pismo z 13 VIII 1945 r. Ze wspomnień L. Kolankowskiego wynika, że to on sam się zgodził na mianowanie tymczasowo J. Wilczyńskiego do prac przygotowawczych, do czasu swojego przyjazdu do Torunia. Por. P. Hübner, Polityka naukowa w Polsce w latach 1944-1953. Geneza systemu, t. 1, WrocławWarszawa-Kraków 1992, s. 105 i n. L. Kolankowski, Pierwsze trzy lata istnienia UMK (1945-1948). Garść wspomnień pierwszego rektora z okresu organizacyjnego, oprac. S. Grochowina, [w:] Ludwik Kolankowski 1882-1956. W pięćdziesiąta rocznicę śmierci, red. W. Sieradzan, Toruń 2006, s. 53 i n. T. P. Rutkowski, Nauki historyczne w Polsce 1944-1977. Zagadnienia polityczne i organizacyjne, Warszawa 2007, s. 51 i n. 
poratowania zdrowia. Z dniem 1 maja 1951 roku nie podjął swoich obowiązków w Toruniu. Przebywał wówczas we Francji i do kraju już nie powrócił. Początkowo podjął wykłady w Bagdadzie, a od 1952 roku w Uniwersytecie Libańskim w Bejrucie. Zmarł w 1970 w Montpellier i tam został pochowany ${ }^{23}$. Na cmentarzu św. Jerzego w Toruniu w grobie jego żony Kazimiery znajduje się urna z ziemią z jego mogiły.

Jan Wilczyński był członkiem szeregu towarzystw naukowych, m.in. Komisji Fizjograficznej PAU, Polskiego Towarzystwa Biologicznego, Polskiego Towarzystwa Naukowego na Obczyźnie, Towarzystwa Przyjaciół Nauk w Wilnie, Towarzystwa Naukowego w Toruniu ${ }^{24}$.

Jan Wilczyński był oficjalnie dwukrotnie żonaty. Pierwszy raz z Alicją z domu Sztejn. Małżeństwo doczekało się dwóch córek: Haliny Zofii (ur. 29 marca 1916 roku), po mężu Rudnickiej, oraz Emilii Krystyny (ur. 21 lutego 1920 roku). 24 czerwca 1931 roku ponownie wstąpił w związek małżeński - po zmianie wyznania z rzymskokatolickiego na ewangelickie - z Kazimierą z domu Urbanowicz (ur. 13 stycznia 1897 roku, zm. 15 stycznia 1980 roku), doktor filozofii w zakresie zoologii USB. Z tego związku urodził się syn Andrzej Paweł (ur. 27 maja 1934 roku, zm. 10 grudnia 2010 roku), profesor Politechniki Warszawskiej ${ }^{25}$.

Wszechnica Batorowa mimo swojej burzliwej historii miała co najmniej jedno szczęście: do dnia dzisiejszego zachował się ogromny materiał źródłowy dotyczący historii USB. Archiwalia przechowuje Lietuvos Centrinis Valstybès Archyvas $(\text { LCVA })^{26}$. Do pierwszego dziesięciolecia działalności USB dysponujemy wspaniałym źródłem, jakim jest drukowana, dwutomowa Księga Pamiatkowa... ${ }^{27}$. Z racji wydarzeń politycznych zapoczątkowanych w 1939 roku drugie dziesięciolecie działalności Uniwersytetu w Wilnie podobnych opracowań się nie doczekało. Nie znaczy to, że materiałów jest mniej. A zawsze o wiele ciekawsze niż urzędowe akta uniwersyteckie są wspomnienia osób uczelnię tę tworzących. Dla przykładu nadal czekają na opracowanie i druk wspomnienia Ryszarda Mienickiego ${ }^{28}$.

W jednym z listów Wiktora Sukiennickiego do syna Bohdana możemy przeczytać taki oto fragment, w którym zastępca profesora teorii i filozofii prawa, jeden z czołowych polskich sowietologów, napisał, że nie spotkał „nauczycieli-mistrzów; ani w do$\mathrm{mu}$, ani w nauce, ani w polityce nie znalazłem autorytetów, którym mógłbym ufać

${ }^{23}$ AUMK, K-1/335, Teczka personalna J. Wilczyńskiego. Por. H. Duczkowska-Moraczewska, M. Gołębiowski, R. Karpiesiuk, B. Kierzkowska, E. Talarczyk, E. Wiśniewska, Pracownicy nauki i dydaktyki Uniwersytetu Mikołaja Kopernika 1945-2004. Materiaty do biografii, red. S. Kalembka, Toruń 2006; Jan Z. Wilczyński, Sprawozdania Towarzystwa Naukowego w Toruniu 1952 z. 1-4; A. Supruniuk, M. A. Supruniuk, Tajemnicze poczatki Uniwersytetu Mikołaja Kopernika (Wilno i Lwów w Toruniu), Torun 2017. Wilczyński Jan Zygmunt, [w:] Pro memoria, oprac. Z. Wajda, Pelplin 2009.

${ }^{24}$ AUMK, K-1/335, Teczka personalna J. Wilczyńskiego, ankieta personalna z 13 czerwca $1950 \mathrm{r}$.

${ }^{25}$ Tamże.

${ }^{26}$ Informator o archiwach z kresów pótnocno-wschodnich Drugiej Rzeczypospolitej w zasobie archiwów białoruskich i LCVA w Wilnie, oprac. J. J. Milewski, Białystok 1996.

${ }^{27}$ Ksiega Pamiątkowa ku uczczeniu CCCL rocznicy założenia i X wskrzeszenia Uniwersytetu Wileńskiego, t. 1: Z dziejów dawnego Uniwersytetu; t. 2: Dziesięciolecie 1919-1929, Wilno 1929.

${ }^{28}$ Biblioteka Uniwersytetu Mikołaja Kopernika w Toruniu, Oddział Zbiorów Specjalnych, Dział Rękopisów, Rps 962II, R. Mienicki, „Wspomnienia”. 
i wierzyć, wodzów za którymi mógłbym iść, ${ }^{29}$. Dla odmiany małżonka wspomnianego uczonego napisała: „W czasie poszukiwań związanych z tezą doktorską, stwierdziłam, że w odróżnieniu od mego męża, jestem za niecierpliwa by skoncentrować się na opracowaniach książkowych, i że raczej interesuje mnie człowiek w jego otoczeniu społecznym. Wróciłam do Wilna i poświęciłam się adwokaturze" ${ }^{\text {"30 }}$.

Prezentowane poniżej wspomnienia Jana Wilczyńskiego dotyczą głównie drugiego dziesięciolecia funkcjonowania USB. Przechowywane są w formie maszynopisu w Dziale Rękopisów pod sygnaturą Rkps 970 Biblioteki Polskiej Polskiego Ośrodka Społeczno-Kulturalnego w Londynie. Sa to materiały redakcyjne do wydawnictwa Pamiętnik Wileński. W teczce 2-3 znajdują się materiały niewykorzystane $\mathrm{w}$ druku, w tym niniejsze wspomnienia. O genezie pomysłu wydania Pamiętnika ... przeczytać można w krótkim wprowadzeniu, a ostatecznie $\mathrm{w}$ drukowanej wersji opublikowano 22 teksty $^{31}$.

W niniejszej edycji tekst wspomnień Jana Wilczyńskiego został przedstawiony wiernie. Zamieszczono wszelkie dopiski autora oraz komentarze redakcji. Tam, gdzie to było możliwe, odczytano skreślenia. Aparat naukowy został ograniczony do przypisów biograficznych, w których krótko przybliżone zostały sylwetki opisywanych osób, oraz do niezbędnych odnośników rzeczowych, w miejscach gdzie autor popełnił jednoznaczne błędy.

Wierzę, że publikowany poniżej materiał będzie zarówno wartościowym przyczynkiem do dziejów Wszechnicy Batorowej, jak i ciekawym źródłem do lektury dla każdego zainteresowanego historią Kresów Północno-Wschodnich.

${ }^{29}$ Instytut Polski i Muzeum Generała Sikorskiego w Londynie (dalej: IPMS), Kolekcja 214 W. Sukiennickiego, sygn. 2, Materiały do życiorysu, list do B. Sukiennickiego z 7 XII 1976.

${ }^{30}$ IPMS, Kolekcja 435 H. Sukiennickiej, sygn. 1, Życiorys i wspomnienia.

${ }^{31}$ Pamiętnik Wileński, wyd. 1: Londyn 1972, wyd. 2: Londyn-Lomianki 2010. 


\section{WSPOMNIENIA}

[odręczny dopisek: nie idzie do druku]

Profesor dr Jan Wilczyński

\section{ZE WSPOMNIEŃ DRUGIEGO DZIESIĘCIOLECIA UNIWERSYTETU STEFANA BATOREGO W WILNIE $(1929-1929)^{32}$}

Pisać o drugim, a jak dotychczas ostatnim, dziesięcioleciu Uniwersytetu Stefana Batorego w Wilnie, bez powiązania z jego wskrzeszeniem w roku 1919, oraz w pierwszym dziesięcioleciu jego istnienia, któremu poświęcono już Księgę Pamiątkową w dwóch grubych tomach, byłoby zadaniem mało wydajnym, gdyż w tym drugim jego okresie Uniwersytet nasz szedł i rozwijał się nadanym mu pędem i w dalszym ciągu tym zasadniczym hasłom, jakie mu nadano przy jego wskrzeszeniu. Można by się spierać, czy i jak te hasła były względnie mogły być, wcielane w życie, ale najbardziej wyróżniającą ich cechą było aby odrodzić w nim nasze „Polskie (lub jeśli kto wolał posługiwać się dawną nutką [wykreślone: natury geograficznej; poprawka: historyczną], to „Litewskie) Ateny". Znaczyło to, że Uniwersytet ten miał być ogniskiem szczerej pracy naukowej oraz przybytkiem kultu prawdziwych cnót, czego ślady możemy znaleźć nawet w końcowych akordach tego drugiego dziesięciolecia, jak można widzieć z dwóch przemówień, wygłoszonych przez ostatniego z czynnych rektorów ${ }^{33}$ tego Uniwersytetu, ks. profesora dra Aleksandra Wóycickiego ${ }^{34}$, a więc mowy na otwarcie roku akademickiego 1938/39 oraz jego wykładu publicznego na temat „Uniwersytet i Społeczeństwo” w tymże dniu 11 października 1938 roku. W przemówieniach tych powoływał się on na to „prastare gniazdo kultury Zachodniej”, które dla „Orła Białego uwił tu wielki król Stefan, a odnowił Marszałek Józef Piłsudski”, skoro pierwszy Rektor tej dawniejszej wszechnicy, którym był rozsławiony ks. Piotr Skarga ${ }^{35}$, w liście swym z roku 1580-go donosił, że Stefan Batory, jadąc z Grodna do Kowna a stamtąd do Wilna ,ubolewał nad

\footnotetext{
32 Zamieszczając w „Pamiętniku Wileńskim” wspomnienia prof. Jana Wilczyńskiego, zmarłego w r. [wykreślone: 1939; poprawka: 1970] niedługo po ich napisaniu, [wykreślone: Komitet; poprawka: Zespół] Redakcyjny zaznacza, że nie podziela wielu opinii i osądów autora, zwłaszcza dotyczących osób czynnych w owym okresie w U.S.B. i zajmujących w nim kierownicze stanowiska. Nie mniej [wykreślone: Komitet Redakcyjny] uznaje wspomnienia prof. Wilczyńskiego za bardzo ciekawy, choć subiektywny obraz osób i stosunków w drugim dziesiątku istnienia USB w Wilnie. Komitet Redakcyjny nadmienia, że prof. Jan Wilczyński należał do grona profesorów USB, którzy w r. 1934 padli ofiarą reformy szkolnictwa wyższego, przeprowadzonej ustawą z dn. 15 III 1933 r., co być może nie pozostało bez wpływu na jego stosunek do kolegów, których uważał za realizatorów lub zwolenników tej reformy — przypis Redakcji „Pamiętnika Wileńskiego".

${ }^{33}$ Stefan Ehrenkreutz, wybrany rektorem na rok akademicki 1939/40, nie mógł już być czynnym ze względu na rozpoczętą w dniu 1.IX.1939 r. wojnę - przypis Autora wspomnień. Stefan Ehrenkreutz (1880-1945), historyk prawa, zastępca profesora i profesor dawnego prawa sądowego polskiego i litewskiego od 1920 r., prorektor USB 1922/1923-1923/1924, rektor 1939/1940. Uwaga Autora wspomnień, że S. Ehrenkraeutz nie mógł być czynnym rektorem, jest błędna. Pełnił on swoje obowiązki do 15 grudnia 1939 r.

${ }^{34}$ Aleksander Wóycicki (1878-1954), ksiądz, profesor Uniwersytetu w Lublinie w 1. 19191937, UJ 1925/1926, USB w 1. 1923/1924-1924/1925, 1926/1927-1939/1940, rektor USB w 1. 1937-1939.

35 Piotr Skarga (1536-1612), jezuita, teolog, pierwszy rektor Uniwersytetu Wileńskiego w 1. 1579-1584.
} 
ciemnotą i nędzą ludu, dla którego widział bijącą w oczy konieczność... podniesienia kraju ze stanu dzikości”. I to właśnie było genezą Wszechnicy Wileńskiej w roku 1578 , która w oczach króla „,miała stać się dźwignią kultury na Północy i Wschodzie Rzeczypospolitej".

Piłsudski ${ }^{36}$ zaś już w dniu 25 kwietnia 1919 roku, przemawiając do Delegacji miasta Wilna, oświadczył: ,że chciałby aby miasto to stało się jedną z wielkich stolic świata, ogniskiem kultury, nowymi Atenami, które promieniowałyby nie tylko na kraj cały, ale i daleko poza jego granicami, i w ten sposób nawiązałyby nić tradycji ze swą świetlaną przeszłością miasta Śniadeckich, Lelewela, Mickiewicza...”. w dniu zaś 28 sierpnia tegoż roku precyzował, aby „Uniwersytet ten promieniował kulturą... podnosił obyczaje, kształcił umysły młodzieży... i był jedna z tych dróg świetlanych, które wiodą ludzkość do poznania prawdy".

Rektor Wóycicki w końcowej części swego przemówienia sprowadzał te dążenia do jednego celu: ,aby postawić Uniwersytet na najwyższym poziomie doskonałości”, a to „w służbie jasnego jak słońce jutra Polski”, zwracając się zaś do młodzieży szczycił się tym, że ,zbiegła się po napój prawdy i cnoty, kiedy do głowy, jak żywe, tłoczą się wspomnienia tak niedawnej jeszcze męczeńskiej naszej przeszłości”. Zajęte przezeń stanowisko było zresztą wielka prawdą.

W obu przytoczonych urywkach nie można dopatrzyć się choćby śladu jakichś tendencji politycznych, a tym mniej partyjnych nawet ze strony Piłsudskiego.

Można z tego wnioskować, że Uniwersytet Stefana Batorego od samego swego wskrzeszenia nawiązywał do dawniejszych tradycji „filomatów i filaretów”, której pozostał wierny również i w ostatnim dziesięcioleciu swego istnienia.

\section{I.}

Czyniąc przegląd wszystkich po kolei rektorów za cały czas istnienia Uniwersytetu Stefana Batorego, przesuwają się przed nami takie postacie, jak jego pierwszy ${ }^{37}$ rektor profesor dr Michał Siedlecki ${ }^{38} \mathrm{z}$ Krakowa, który po kilku odmownych pertraktacjach ze strony innych, może więcej podówczas popularnych i wpływowych kandydatów, jak np. prof. Jan Rozwadowski ${ }^{39}$, przyjął to stanowisko, opierając się również na współpracy ze swym kolegą i przyjacielem prof. Emilem Godlewskim jun. ${ }^{40}$, obaj zaś starali się nadać od samego początku nowemu Uniwersytetowi kierunek haseł uniwersytetu dawniejszego sprzed wieku.

${ }^{36}$ Józef Piłsudski jako Naczelny Wódz wydał 28 sierpnia 1919 r. rozkaz, na mocy którego 10-11 października 1919 r. reaktywowano w Wilnie uniwersytet.

${ }^{37}$ Poprzednie próby uruchomienia Uniwersytetu Wileńskiego były robione przez społeczeństwo Polskie w Wilnie, a zgodnie z zapadłą decyzją Komitetu Polskiego w Wilnie z dnia 28 XII 1918, Senat ukonstytuował się w składzie następującym: rektor profesor Józef Ziemacki, profesor Alfons Parczewski, dziekan Wydziału Prawa i Nauk Społecznych, profesor Ptaszycki, dziekan Wydziału Filozoficznego, profesor S. Władyczko, dziekan Wydziału lekarskiego. Ponadto w skład jego weszli: prof. Wł. Zawadzki, K. Noiszewski, i dr. S. Kościałkowski. Potem organizatorem został Ludwik Kolankowski a dopiero wtedy Adam Wrzosek, dyrektor Departamentu Szkół Akademickich powołał na stanowisko Rektora prof. Michała Siedleckiego — przypis Autora wspomnień

${ }^{38}$ Michał Siedlecki (1873-1940), profesor zoologii UJ od 1903 r., profesor zoologii USB w 1. 1919-1921, pierwszy rektor USB w 1. 1919-1921.

39 Jan Rozwadowski (1867-1935), prof. językoznawstwa indoeuropejskiego UJ od 1899 r.

${ }^{40}$ Emil Godlewski junior (1875-1944), profesor anatomii opisowej i embriologii UJ od $1906 \mathrm{r}$. 
Zresztą prof. Siedlecki był nie tylko prawdziwym patriotą, człowiekiem wysoce kulturalnym i sprawie całkowicie oddanym, ale również, w poprzednich latach, naukowcem na polu zoologii wartościowym i zasłużonym, i tymże celom chciał nadal służyć.

Oczywiście, nie był on pozbawiony, jak każdy człowiek na świecie, również i pewnych wad: był gadułą; więcej obiecywał niż dotrzymywał; nierzadko nie miał własnego zdania; łatwo ulegał wpływom kolegów z Krakowa i Lwowa i w ogóle był bardziej pro-galicyjski niż ogólnopolski. W ostatnim, a więc drugim, nie licząc się wcale z możliwością jej realizacji, tak iż zadawalał się pozorami: „utaliquidfecissevideatur”, wskutek czego zaczął napotykać pewnego rodzaju opozycje, a nawet pewnego razu spotkał się z poufnie wypowiedzianą mi uwagą ze strony najgoręcej oddanego duchowi Wilna i najbardziej wiernego jego czciciela prof. Ludwika Janowskiego ${ }^{42}$ ze złośliwie krytycznym i rozjątrzonym wykrzyknikiem „Ależ jemu (Siedleckiemu) się zdaje, że jest już prawdziwym Dalaj-Lamą Tybetańskim”.

Gdy jednak Siedlecki nie dał się namówić (pomimo czynionych starań) na pozostanie na stałe w Wilnie i powrócił, nieco speszony, w roku $1922^{43}$ do rodzimego Krakowa, następcy jego na krześle rektorskim wszyscy bez wyjątku, trzymali się tego ducha dawnego Wilna, modyfikując go jedynie cechami własnych zindywidualizowanych charakterów.

Pierwszym po Siedleckim Rektorem został wybrany Wiktor Staniewicz ${ }^{44}$, profesor wyższej matematyki z Instytutów Petersburskich, wzór spokoju, ścisłości i porządku w całym swym zachowaniu się, [wykreślone: i również był] znany wśród studenterii ze swych zawsze najskrupulatniejszych wykładów, jak najspokojniej i jak najsystematyczniej wygłaszanych. W rektorskich swych rządach wolał się nie wtrącać w sprawy innych wydziałów, pozostawiając to dziekanom, lub oddając bardzo często rządy czy troski w ręce Sekretarza Generalnego Uniwersytetu dr Walentyny Horoszkiewiczówny $^{45}$ (z Krakowa), która mocno, o ile nie wszechwładnie, trzymała ster w swym ręku „byle we wszystkim był porządek”. W związku z jej pobytem w Wilnie zasługuje na podkreślenie fakt [wykreślone: jedyny w swoim rodzaju], że podczas gdy cała ludność Polska została ewakuowana pod koniec wojny, jeśli pamięć mnie nie myli (w pociągach towarowych z Wilna do Polski) nazywało się to „repatriacją”, to dr Horoszkiewiczówna odmówiła udziału w tej „repatriacji”, będąc, jak mówiono, przepełniona niezłomną wiarą, że Wilno wkrótce odzyskamy [wykreślone: że w nim]. Pozostała w nim całkiem osamotniona, otaczając swą opieką po ks. prof. Żongołłowiczu ${ }^{46}$ bogatą bibliotekę teologiczną, z którą nie wiadomo co się następnie stało, gdyż w niedługim czasie dr Horoszkiewiczówna zapadła na ciężką chorobę raka i zmarła.

Po Wiktorze Staniewiczu, berło rektorskie przeszło z kolei w ręce prof. Alfonsa Parczewskiego $^{47}$ (1922/23 i 1923/24), profesora prawa kościelnego, bolejącego nad

${ }^{41}$ Tłum.: by się (co najmniej) wydawało, iż się coś (w tej kwestii) dzieje.

${ }^{42}$ Ludwik Janowski (1878-1921), rektor Polskiego Kolegium Uniwersyteckiego w Kijowie do 1919 r., profesor literatury ruskiej UJ 1919, profesor historii kultury USB w 1. 1919-1921.

${ }^{43}$ M. Siedlecki przestał być profesorem w Wilnie z dniem 30 września $1921 \mathrm{r}$.

44 Wiktor Staniewicz (1866-1932), profesor matematyki USB od 1919 r., rektor USB w 1. 1921-1922.

${ }^{45}$ Walentyna Horoszkiewicz (Horoszkiewiczówna) (1890-1949), studentka Wydziału Filozoficznego UJ, dr filozofii (filologia polska) USB 1933, sekretarz USB w 1. 1921-1937.

${ }^{46}$ Bronisław Żongołłowicz (1870-1944), profesor prawa kanonicznego USB od 1919 r., wiceminister wyznań religijnych i oświecenia publicznego w 1. 1930-1936.

${ }^{47}$ Alfons Parczewski (1849-1933), profesor prawa kościelnego UW w 1. 1915-1919, profesor prawa kościelnego USB od 1919 r., rektor USB w 1. 1922-1924. 
stopniowym kurczeniem się zasięgu panowania kultury Polskiej w przeszłości i tym goręcej pomimo podeszłego wieku (ur. 1849) troszczącego się o jej odbudowę i uprawomocnienie okresie odzyskanie niepodległości [wykreślony nieczytelny fragment].

Następnie z kolei rektorat przeszedł $\mathrm{w}$ ręce prof. Władysława Dziewulskiego ${ }^{48}$ (1924/25), oddanego [wykreślone: w swej astronomii] swej astronomii, pilnie i precyzyjnie dbającego o dalszy rozwój Uniwersytetu Wileńskiego we wszystkich dziedzinach, choć równocześnie uległego wpływom lub sympatiom osobistym, nie pozbawionym również pewnych predylekcji dzielnicowych.

Po W1. Dziewulskim wybranym został prof. Marian Zdziechowski ${ }^{49}$ (1925/26). Poziom jego rozwoju, bogactwo twórczości naukowej na polu literatur europejskich, które były przedmiotem jego licznych prac z zakresu panslawizmu, mesjanizmu, pesymizmu, religioznawstwa i rozwoju ideologii narodowej, jak niemniej hasła, które starał się wpoić w swe otoczenie w ogóle, [wykreślone: jak] oraz nakłonić do nich młodzież, do której kierował swe liczne przemówienia (zebrane i wydane następnie w liczbie 11-tu w oddzielnej książeczce pod tytułem: „Walka o duszę młodziė̇y” Wilno, 1927 r.) czyniły zeń jednostkę najwybitniejszą całego Uniwersytetu. Wszystkie te przemówienia skierowane były przeciw krzewiącemu się coraz bardziej bolszewizmowi, który traktował jak „,bestializację kultury ludzkiej" przez jej zmaterializowanie, czemu przeciwstawiał religię i patriotyzm wykluczając jednak wszelkie przerosty nacjonalistyczne, wołając ,miejcie litość nad Ojczyzną". Podkreślając rolę Polski jako ,antemurale Christianitatis” występował przeciw wszelkiego rodzaju partyjniactwu, wysuwał natomiast starogrecką zasadę Platona „królewskiej sztuki wzajemnego przenikania się umysłów” a to przez „,wyczucie powinności", jako drogi dalszego rozwoju, wypowiadając się jednocześnie przeciw stosowaniu jakiejkolwiek propagandy. Walcząc równocześnie przeciw kapitalizmowi, który upodabniał do olbrzyma Leviatana, wyzyskującego świat przy pomocy Towarzystw Akcyjnych, wskazywał „na miliony zagłodzonych, miliony wymordowanych, miliony torturowanych przez bolszewizm istot” i wzywał [wykreślone: do] by „ratować [wykreślone: choroba] Ojczyznę, otwierać oczy na chorobę, która toczy Europę i nas, tak mało odpornych”, ostrzegał przed „zarazą bolszewizmu, grasującą w Wilnie i całym naszym kraju”, [wykreślony fragment nieczytelny] cytował słowa rosyjskiego działacza społecznego D. Miereżkowskiego ${ }^{50}$, który uciekając $\mathrm{z}$ Rosji wygłosił był w Uniwersytecie Stefana Batorego, w roku 1920, odczyt, w którym twierdził, że ,albo będzie bolszewizm i nie będzie Polski albo odwrotnie"s1.

Dziś trudno by odmówić o Zdziechowskim swego rodzaju proroczego wyczucia tej przyszłości, której jesteśmy świadkami, ale wówczas przemówienia jego osiągały najwyższy poziom zorientowania i wpływów, tak iż bez żadnej wątpliwości zajął on zarówno wśród wszystkich rektorów, jaki i profesorów Uniwersytetu Stefana Batorego najwyższe szczytowe miejsce, był prawdziwie „numerem pierwszym” całego zespołu nauczających, przez nikogo nieprześcignionym. Cechowała go wielka wszechstronność

${ }^{48}$ Władysław Dziewulski (1878-1962), profesor astronomii USB od 1920 r., rektor USB w 1. 1924-1925.

${ }_{49}$ Marian Zdziechowski (1861-1938), profesor literatury powszechnej USB od 1919 r., rektor USB w 1. 1925-1927.

${ }^{50}$ Dmitrij Miereżkowski (1865-1941), poeta i pisarz rosyjski, po rewolucji bolszewickiej uciekł do Polski, a następnie osiadł w Paryżu.

${ }^{51}$ Bardzo to podobne do wypowiedzianego przekonania Napoleona, że ,,aussi Longtemps que la Pologne ne sera pas retablie, l'EuropeOccodental sera sans frontieres du Cote de l'Asie" - przypis Autora wspomnień. Tłum.: Dopóki Polska nie odzyska niepodległości, Europa Zachodnia będzie pozbawiona granicy na pograniczu z Azją. 
w zakresie badań oraz gruntowność analiz i dokumentowania, które przepajało dążenie do podniesienia poziomu naszej, a właściwie nawet ogólnoeuropejskiej, czy światowej kultury w ogóle. Przy tym odznaczał się pewną nerwowością czy przewrażliwieniem w stosunku do wszelkich przeżyć naszego narodu, co prawdopodobnie było też powodem wysunięcia przez J. Piłsudskiego jego kandydatury na Prezydenta Rzeczypospolitej po przewrocie majowym w roku 1926. Kandydatury tej Zdziechowski nie przyjął, a następnie zrzekł się $w$ pierwszej połowie drugiego roku swego rektoratu tego nawet urzędu, być może właśnie z powodu jego opozycji względem wzmagających się wpływów na życie uniwersyteckie polityki BBWR ${ }^{52}$.

Następcy jego na krześle rektorskim: zarówno znany badacz i wielki wielbiciel Mickiewicza Stanisław Pigoń ${ }^{53}$ (1927/28) jak i następnie teolog ks. prof. Czesław Falkowski $^{54}(1928 / 29$ oraz 1929/30) pozostali wierni zasadom wytkniętym przez M. Zdziechowskiego, pilnie strzegąc autonomii uniwersyteckiej oraz wolności sądów od wpływów politycznych.

\section{II.}

Tenże ks. Rektor Czesław Falkowski, ponownie wybrany na rok 1929/30 wprowadza nas już w drugie dziesięciolecie istnienia USB, które jest właściwym przedmiotem niniejszych wspomnień. Był to $\mathrm{w}$ prawdziwym tego słowa znaczeniu wykształcony duchowny katolicki w służbie narodowej, który poprzez krytykę protestantyzmu i reformacji, a umiłowanie ideologii św. Franciszka, składał kolejno hołdy czci naszej Konstytucji 3 Maja, pamięci Tadeusza Kościuszki oraz sprowadzonych zwłok Słowackiego $^{55}$, aby ująć to wszystko w jednym wyrazie swego przemówienia inauguracyjnego w roku 1928, Sic itur ad astra ${ }^{56}$.

Co jednak okres tego drugiego dziesięciolecia najbardziej charakteryzuje to atmosfera niestety pożałowania godnego rozdwojenia politycznego, jakie zaciążyło zarówno na całej Polsce jak i dało się we znaki na Uniwersytecie Stefana Batorego w Wilnie. Źródłem tego rozdwojenia z całą pewnością był wciąż tenże przewrót majowy 1926 roku oraz poprzedzające go a niewygasłe walki toczące się w Sejmie. Znalazło to wyraz w utworzeniu tzw. „Bezpartyjnego Bloku Współpracy z Rządem”,

Jakkolwiek to $\mathrm{w}$ niczym nie zmieniło kierunku $\mathrm{w}$ dziedzinie polskiej polityki zagranicznej, której trudno było coś poważnego zarzucić, ani też znaleźć konkretne możliwości realizacji polityki odwrotnej [wykreślone: przeciwniemieckiej], to jednak poli-

${ }^{52}$ Bolszewicy nie mogli już zemścić się na Zdziechowskim za całą jego przeciw nim skierowaną działalność, gdyż w roku 1939 już nie żył, wywieźli za to jego jedynego syna, który we wszystkim był ducha winien ponoć nawet pomylony, w każdym bądź razie poważnie, na skutek wrodzonej nadmiernej otyłości chory, i tam został zgładzony — przypis Autora wspomnień.

${ }^{53}$ Stanisław Pigoń (1885-1968), zastępca profesora i profesor historii literatury polskiej USB w 1. 1921-1931, rektor USB w 1. 1927-1928, profesor historii literatury polskiej UJ od $1931 \mathrm{r}$.

${ }^{54}$ Czesław Falkowski (1887-1969), profesor historii kościoła USB od 1921 r., rektor USB w 1. 1928-1930.

${ }^{55}$ Juliusz Słowacki (1809-1849), polski poeta epoki romantyzmu, jeden z Wieszczów Narodowych, sprowadzenie jego prochów do Polski i złożenie ich w Bazylice Archikatedralnej na Wawelu miało miejsce w $1927 \mathrm{r}$.

${ }^{56}$ Cytat z Wergiliusza, tłum.: „Tak się idzie do gwiazd”. Niemniej dewizą USB był zmieniony tekst: „Hinc itur ad astra”, czyli „Stąd się idzie do gwiazd”.

${ }^{57}$ Bezpartyjny Blok Współpracy z Rządem - organizacja polityczna działająca w Polsce w 1. 1927-1935 mająca wspierać politykę ,sanacyjną” J. Piłsudskiego. 
tyka tego bloku gruntownie podkopała naszą spoistość wewnętrzną, bardzo osłabiając nasze państwo. Zamiast naród nasz, podzielony po przeszło 120 latach trwających rozbiorów, za wszelką cenę zespolić w trwałej zgodzie, to swym zamachem majowym i swą polityką J. Piłsudski tylko go znów podzielił. Można by zaryzykować nawet twierdzenie, że jeżeli na polu naszej polityki zewnętrznej okazał się Piłsudski wielkim odnowicielem i budowniczym, prawdziwym mężem stanu, którego otaczał mir powszechny i z którego udatnie i szczęśliwie mogli współpracować Dmowski ${ }^{58}$ i Paderewski ${ }^{59}$ wywalczając dla odrodzonej Polski nowe granice Traktatu Wersalskiego ${ }^{60}$, to jego posunięcia na polu polityki wewnętrznej nie mogłyby zasłużyć na inne określenie, jak tylko pożałowania godne.

Nie byłoby słusznym jednak pominąć tej ciekawej okoliczności, o której słyszałem z ust śp. Tomasza Czernickiego ${ }^{61}$, przewodniczącego Stronnictwa Chłopskiego w Sejmie, że Piłsudski, w pełni ekspansji tego BBWR, miał użalać się [wykreślone: swemu przyjacielowi] posłowi Stanisławowi Thuguttowi ${ }^{62} \mathrm{z}$ „Wyzwolenia”, że „czuje się jakby go wszy oblazły". Te bardzo charakterystyczne dla sposobu jego wyrażania się słowa mogłyby wskazywać chyba na wstręt do wszelkiego karierowiczowstwa i wykorzystywanie wpływów politycznych dla celów osobistego powodzenia przy obsadzie stanowisk czy posad, i to najczęściej w formie bezapelacyjnie od góry narzuconej.

Cierpiał na tym również i Uniwersytet Stefana Batorego w Wilnie. Wpływy BBWR zaczęły przenikać na poszczególne wydziały, dzieląc je na dwa przeciwstawne sobie i wzajemnie zwalczające się obozy, miast poprzedniego uszanowania cudzego zdania i dużej obojętności względem tych czy innych przekonań politycznych. Wskutek tej zmiany tworzyły się na Wydziałach większe lub mniejsze partyjki, najczęściej wypływające nawet $\mathrm{z}$ różnic dzielnicowych, współzawodnictwa czy też animozji osobistych i te zaczęły odgrywać rolę w takich sprawach jak wybory dziekanów, rektorów czy nawet członków poszczególnych komisji wydziałowych, a to znowu nierzadko prowadziło do zrywania stosunków osobistych lub podstępnego i ukrytego szkodzenia sobie wzajemnie. W ten sposób starodawne hasło Uniwersytetu Wileńskiego „Ojczyzna, Wiedza i Cnota" uległo pewnemu przyćmieniu, odsuwało się na dalszy plan, o ile nie znikało w ogóle.

Dało mi to podstawę do napisania odrębnej rozprawy w formie niewielkiej książeczki zatytułowanej „O dobrych zwyczajach Akademickich i potrzebie ich chowania w Polsce" i wydanej przez Kazimierza Rutskiego ${ }^{63}$ w Wilnie, w liczbie, o ile mię pamięć nie myli, 1500 egzemplarzy.

Rozprawa ta wywołała dużo hałasu i zdań rozmaitych. Byłem i pozostaję prawdziwie zaszczycony nadesłanymi mi wyrazami uznania przez tak wybitnych profeso-

${ }^{58}$ Roman Dmowski (1864-1939), mąż stanu, polityk związany z narodową demokracją, m.in. delegat Polski na Konferencję Pokojową w Paryżu.

${ }^{59}$ Ignacy Jan Paderewski (1860-1941), pianista, mąż stanu, prezydent ministrów i minister spraw zagranicznych 1919, delegat Polski na Konferencję Pokojową w Paryżu.

${ }^{60}$ Traktat Wersalski - traktat pokojowy zawarty przez państwa Ententy z Niemcami 28 czerwca 1919 r. kończący pierwszą wojnę światową.

${ }^{61}$ Tomasz Czernicki (1886-1947), poseł na Sejm z ramienia Stronnictwa Chłopskiego (od 1931 r. - Stronnictwa Ludowego) w 1. 1928-1929, 1930-1935.

${ }^{62}$ Stanisław Thugutt (1873-1941), publicysta, polityk, działacz PSL „Wyzwolenie” i jego prezes w 1. 1921-1924.

${ }^{63} \mathrm{~J}$. Wilczyński, O dobrych zwyczajach akademickich i potrzebie ich chowania w Polsce, Wilno 1932. Kazimierz Rutski (1867-1945), księgarz i wydawca w Wilnie. 
rów jak Tadeusz Zieliński ${ }^{64}$ i K. Ujejski ${ }^{65}$ z Warszawy oraz Marian Zdziechowski z Wilna, aby wymienić najpoważniejszych, ale w samym środowisku Wileńskim wywołało to dużo sprzeciwów i opozycji. Zarzucano mi „wtrącanie się nie w swoje sprawy", szczególniej miał być oburzony prof. Ehrenkreutz [wykreślony nieczytelny fragment], ale wydawnictwo to bardzo prędko się rozeszło, a nawet miałem pewne podejrzenie czy nie zostało po prostu wykupione przez kogoś z przeciwników. Spełniłem jedynie swój obowiązek.

W imię prawdy, należy podkreślić, że Uniwersytet Stefana Batorego potrafił również przeciwstawić się takim z góry narzucanym wpływom politycznym. Na Wydziale Lekarskim na przykład, w ciągu nieomal 5-ciu lat z kolei był obierany na Dziekana prof. Zenon Orłowski ${ }^{66}$, chociaż wyraźnie był przeciwny polityce BBWR. To samo działo się i na innych wydziałach, zależnie od poszczególnych, często zmieniających się wpływów i tendencji.

Dużo więcej w tej dziedzinie zależało od osoby wybieranego Rektora. W ten sposób, jeżeli np. rektorowie M. Zdziechowski, St. Pigoń i ks. Cz. Falkowski nie ulegali żadnym wpływom polityki z góry narzucanej pozostając wiernymi zasadom autonomii Uniwersyteckiej oraz niezależności przekonań, to ich następcy zaczęli wykazywać już pewną uległość i widoczne zróżnicowanie w swych decyzjach.

Pierwszy i całkiem wyraźny wpływ BBWR wyjawił się przy wyborze na Rektora profesorów Aleksandra Januszkiewicza ${ }^{67}$, a następnie, i już w dużo większym stopniu, Witolda Staniewicza ${ }^{68}$.

Były jednakże pomiędzy nimi znaczne różnice: dr Januszkiewicz [odręczny dopisek: (1930/31 i 1931/32)] praktykujący lekarz z Kijowa i profesor Kliniki Wewnętrznej w Wilnie, dość bezbarwny pod względem politycznym i nie mogący się wykazać właściwie żadnym dorobkiem naukowym, ani też [wykreślone: jakąkolwiek] poprzednią działalnością pedagogiczną, najczęściej wolał nie angażować się w jakiekolwiek spory i unikał jasnych rozstrzygnięć, zachowując zazwyczaj ukrytą w sobie samym diagnozę wypadków (podobnie jak to lekarz bardzo często nie zdradza przed swym pacjentem diagnozy jego choroby). Ale, pomimo swej niezaprzeczalnej uczciwości osobistej, starał się on wykorzystywać swój rektorat dla zwiększenia swej wziętości jako praktykujący lekarz w mieście, oraz szukał [wykreślone: w najlepszym razie] oparcia w nowej polityce jedynie dla celów zwiększenia dotacji Uniwersyteckich i to mając na względzie na pierwszym miejscu zaopatrzenie Wydziału Lekarskiego.

Podkreślić muszę bardzo wysokie kwalifikacje następnego rektora, jakim był Kazimierz Opoczyński $^{69}$ (1932-33), profesor histologii na Wydziale Lekarskim.

Kazimierz Opoczyński, choć z pochodzenia Podolanin czy Kijowianin, wyróżniał się, obok [wykreślone: szczerości] szczerego patriotyzmu, poczuciem bardzo wielkiej odpowiedzialności za każde swe posunięcie, zawsze niezachwianą bez stronnością i ścisłością we wszystkich swych twierdzeniach, jak niemniej nieubłaganie śmiałym

${ }^{64}$ Tadeusz Zieliński (1859-1944), profesor filologii klasycznej UW od 1920 r.

${ }^{65}$ właśc. Józef Ujejski (1883-1937), profesor historii literatury UW od 1919 r.

${ }^{66}$ Zenon Orłowski (1871-1948), profesor diagnostyki i terapii ogólnej chorób wewnętrznych USB od 1922 r.

${ }^{67}$ Aleksander Januszkiewicz (1872-1955), profesor szczegółowej patologii i terapii chorób wewnętrznych od 1921 r., rektor USB w 1. 1930-1932.

${ }^{68}$ Witold Staniewicz (1887-1966), polityk, profesor ekonomii politycznej USB od 1931 r., rektor USB w 1. 1933-1936.

${ }^{69}$ Kazimierz Opoczyński (1877-1963), profesor anatomii patologicznej USB od 1922 r., rektor USB w 1. 1932-1933. 
i upartym krytycyzmem przy rozpatrywaniu każdego nasuwającego się zagadnienia, a równocześnie zawsze wielkim taktem i wewnętrzną wyrozumiałością i dobrocią swego charakteru.

Szczery i doświadczony wyznawca autonomii uniwersyteckiej zwierzał się on o tych wielkich trudnościach, jakie go spotykały, gdy musiał się liczyć z dość częstą w owym roku obecnością, a więc i wywieranymi wpływami, Prezesa Rady Ministrów Janusza Jędrzejewicza $^{70}$, gdy ten przyjeżdżał często do Wilna i wówczas lubił się wtrącać do spraw uniwersyteckich. I atmosfera stawała się wówczas dość napięta.

Witold Staniewicz miał oblicze bardziej wyraźne z jego własnych przekonań wypływające. Jego wielkim plusem było że pochodził z tejże ziemi wileńskiej, której miał służyć na stanowisku Rektora. W żaden sposób nie dałoby się negować, że z pewnością miał chęci jak najlepsze. Ale była to kandydatura wysunięta przez okoliczności natury politycznej, gdyż chciano wykorzystać jego prawdziwe oddanie ideologii Piłsudskiego. Za to dużo mniej był przygotowany do zajmowania tego stanowiska z punktu widzenia czysto akademickiego.

Jako absolwent Wydziału Filozoficznego Uniwersytetu Jagiellońskiego w Krakowie wykonał on pracę z zakresu zoologii u prof. Siedleckiego nad wymoczkami, która nie pozostawała $\mathrm{w}$ żadnym związku z zagadnieniami rolnictwa. I chociaż, następnie, poświęcił się ekonomice rolnictwa, studiując na Wydziale Rolniczym Politechniki w Monachium, gdzie uzyskał stopień inżyniera rolnictwa, ale swoją pracę doktorską z roku 1926-go poświęcił charakterystyce gospodarki rolnej w majątku żony Wersoce Wielkiej $^{71}$. Poświęcał się zresztą raczej działalności administracyjnej, rozumiejąc ją z pewnością jako służbę na rzecz kraju.

Rozpoczął ją na stanowisku starosty trockiego w Zarządzie Cywilnym Ziem Wschodnich. Zaangażowany na Uniwersytecie Stefana Batorego najpierw w charakterze asystenta przy katedrze ekonomii politycznej na Wydziale Prawnym, skąd, w związku z otwarciem Studium Rolniczego w roku 1924, został powołany na docenta ekonomiki agrarnej, następnie wysunięty jako kandydat na katedrę tejże ekonomiki. Uzależnił on przyjęcie zaproponowanej mu w roku 1926 teki ministra reform rolnych w rządzie Piłsudskiego, od formalnego przyrzeczenia mu nominacji na katedrę. Gdy to zostało pomyślnie załatwione, wówczas przyjął tekę ministra.

Wybór na Rektora zawdzięcza on nie w małej mierze swemu poprzedniemu stanowisku Ministra, zawsze i powszechnie bardzo honorowanemu, jak też swemu gorącemu popieraniu polityki Piłsudskiego. W rzeczywistości katedrę zdobył on swą teką Ministra, a następnie Rektorat godnością swego stanowiska w Rządzie Rzeczypospolitej.

Ale ówczesne rozgrywki polityczne i atmosfera uległości względem BBWR, której Witold Staniewicz chcąc nie chcąc musiał hołdować sprawiły, że rektorat jego wciąż był odnawiany i trwał całe trzy lata akademickie z kolei od 1933/34 do 1936/37, w ciągu których Polska była poddawana polityce z góry narzuconych wpływów i wszelkiego rodzaju staraniom niweczenia tendencji opozycyjnych czy wręcz bezpartyjnych.

Na okres rektoratu Witolda Staniewicza przypadła również głośna podówczas sprawa zwijania katedr na Uniwersytetach i przenoszenia zajmujących je profesorów w stan nieczynny. Zainicjowana i urzędowo przeprowadzona przez Janusza Jędrzejewicza, jako Prezesa Rady Ministrów, brała jednak ona nierzadko swe źródło w samych

\footnotetext{
${ }^{70}$ Janusz Jędrzejewicz (1885-1951), polityk, Prezes Rady Ministrów w 1. 1933-1934, minister wyznań religijnych i oświecenia publicznego w 1. 1931-1934.

${ }^{71}$ Jest to błąd Autora wspomnień. Witold Staniewicz uzyskał doktorat $\mathrm{z}$ filozofii w zakresie zoologii w UJ w $1911 \mathrm{r}$. na podstawie rozprawy: „Badania doświadczalne nad trawieniem thuszczy u wymoczków”. Natomiast opublikował monografię Dwór Wersoka Wielka (Wilno 1926).
} 
Uniwersytetach, gdzie partyjno-prorządowe ugrupowania występowały z potajemnie wysuwanymi wnioskami o zlikwidowanie tego lub owego - najczęściej najbardziej odpornego i niezależnych przekonań profesora. Przypadł i mnie w udziale ten zupełnie niezasłużony „,zaszczyt” należenia do przeniesionych w stan nieczynnych profesorów przez zwijanie ich katedr na Uniwersytecie Stefana Batorego w Wilnie. Do takich, oprócz mnie, na Wydziale Lekarskim należeli zasłużeni profesorowie Zenon Orłowski oraz Stanisław Władyczko ${ }^{72}$, a na innych wydziałach profesor Stefan Glaser ${ }^{73}$ z katedry prawa kryminalnego oraz Stefan Glixelli ${ }^{74}$ z katedry romanistyki, jak również nawet już emerytowany profesor i były rektor Marian Zdziechowski, któremu pierwotnie cofnięto prawo kontynuowania wykładów, cieszących się zawsze wielką frekwencją. Z pośród 38-miu innych usuniętych profesorów na innych Uniwersytetach znalazło się wielu całkiem niezależnych i zasłużonych naukowców i dobrych obywateli kraju.

Dziś z niesmakiem można jedynie wspominać sobie ten akt tak karygodnej bezmyślności ze strony ministra Janusza Jędrzejewicza, który stawiał politykę wyżej od nauki i nie zdawał sobie sprawy jak bardzo Polska potrzebowała (a i wciąż potrzebuje) kształcenia kadr profesorskich i ich zdyscyplinowania, wewnętrznej zgody i jedności, nie zaś ciągłych konfliktów i rozterek.

Ponadto, w ostateczności każdy z usuniętych profesorów przechodził na emeryturę, obarczając bezużytecznie Skarb Państwa i musiał szukać innego zatrudnienia w kraju lub zagranicą, przemilczając doznany na gładkiej drodze szok natury politycznej.

Rektor Staniewicz, jak i rektorzy innych Uniwersytetów, uparcie milczeli odbiegając $\mathrm{w}$ ten sposób od starodawnej niezawisłości pracy akademickiej. Z ubolewaniem można było to stwierdzić w stosunku do Witolda Staniewicza, który z drugiej strony, był człowiekiem dobrze wychowanym, uprzejmym i z pewnością nie żywił żadnych złych zamiarów natury osobistej.

Wreszcie ostatnim z czynnych (w ciągu dwóch kolejnych lat 1937/38 i 1938/39) rektorów był ks. Aleksander Wóycicki, profesor chrześcijańskich nauk społecznych, którymi głównie w swych przemówieniach, kazaniach lub wydrukowanych rozprawach się interesował, przepełniając je głębokim umiłowaniem i wiarą, które bardzo go zbliżały do starodawnych tradycji i ideologii Uniwersytetu Wileńskiego, sprzed wieku.

Demokrata z przekonania i upodobań szukał on rozwiązania bolączek społecznych, którym przewodził czy raczej nad którymi górował szczery patriotyzm polski. W jego przemówieniu na otwarcie roku akademickiego 1938/39 można znaleźć wyznanie, jak że „W pełni urzeczywistniamy się przez naszą solidarność z rodakami” (a to wbrew stanowisku Fr. Nietschego ${ }^{75}$ „o kulcie egoistycznym jednostki”), że „człowiek żyje w społeczeństwie dla społeczeństwa”, że ,nigdy czasy nie były tak płodne, w jednostki tak silne, jak te kiedy rodzina była mocna i czczona”. „Wszechnica Batorowa według niego miała przygotować rycerzy Kultury Zachodniej XX-go wieku” i to „na przedpolu cywilizacji łacińskiej”, iżby ,stoczyć bój z bolszewizmem o ideał polski i chrześcijański”.

[wykreślone: po to tylko, by życie prowadzić dalej w warunkach lepszych „bo wojnę prowadzimy z dziczą, jakiej dzieje nie znały jeszcze nigdy: z bolszewizmem”, w ten sposób „Wszechnica Batorowa miała według niego przygotować rycerzy Kultury

\footnotetext{
${ }^{72}$ Stanisław Władyczko (1878-1936), profesor neurologii i psychiatrii Instytutu Psychoneurologicznego w Petersburgu, profesor neurologii USB w 1. 1919-1933.

${ }_{74}^{73}$ Stefan Glaser (1895-1984), profesor prawa i procedury karnej USB w 1. 1924-1934.

${ }^{74}$ Stefan Glixelli (1888-1938), zastępca profesora i profesor filologii romańskiej USB w 1. 1919-1933, lektor języka polskiego w Uniwersytecie w Bukareszcie w 1. 1934-1937, profesor filologii romańskiej UJ w 1. 1937-1938.

${ }^{75}$ Friedrich Nietzsche (1844-1900), niemiecki filozof.
} 
Zachodniej XX-go wieku” i to „na przedpolu cywilizacji łacińskiej”, iżby „stoczyć bój z bolszewizmem o ideał polski i chrześcijański”].

Niestety hasła te, jakkolwiek zarówno słuszne i całkiem zrozumiałe, jak idące po linii dawnych haseł Uniwersytetu Wileńskiego, nie dawały się już wcielić w życie, gdyż ze strony hitlerowskich Niemiec już się dawały wyczuć groźby przyszłej napaści i pogrążały wszystkich w wielki niepokój i niepewność jutra.

To też po ukończeniu rektoratu ks. A. Wóycickiego nowoobrany na wiosnę 1939 rektorem Stefan Ehrenkreutz, profesor historii dawnego prawa sądowego polskiego i litewskiego, będąc tym ostatni z rektorów USB, nie mógł być rektorem czynnym z powodu wybuchu w dniu 1 września 1939 roku drugiej wojny światowej, a wraz $\mathrm{z}$ nią natychmiastowego rozstroju i głębokich powikłań w życiu społecznym zarówno całego kraju, jak i Wileńszczyzny. Wybór ten jednak mógłby świadczyć o [wykreślone słowo nieczytelne] wzroście pewnych tendencji lewicowych, gdyż od dawna było wiadome, że Ehrenkreutz jest członkiem PPS oraz człowiekiem bezwzględnym i zawsze nerwowym i podirytowanym, względnie często ponurym i jakby czegoś zakłopotanym, zawsze amatorem narzucania sądów innym. Był to człowiek powszechnie nielubiany. Nie należałoby jednak z tego wnioskować, że był niewłaściwym człowiekiem na niewłaściwym miejscu, bo wyobrażam sobie, że jako profesor prawa sądowego musiał być zawsze gruntownie i detalicznie przygotowany do wykładów, a w swych twierdzeniach uparty i nie dopuszczający żadnych sprzeciwów. Podejrzewam, że może właśnie te cechy charakteru wysunęły go na krzesło rektorskie, w nadziei że sprosta swym zadaniom zarówno we wciąż toczącej się walce o autonomię uniwersytecką z Ministerstwem WRiOP i rządem w ogóle, a to w atmosferze wciąż pogłębiających się gróźb i niepokoju ze strony Niemiec.

Te może nie całkiem pochlebne uwagi w żaden sposób nie mogą umniejszyć jego niezłomnego stanowiska w walce, z pewnością często ciężkiej, gwałtownej i beznadziejnej o zachowanie Uniwersytetu Stefana Batorego w Wilnie, i to z Litwinami opierającymi się o Sowiety po zagarnięciu przez nich Wileńszczyzny w drugiej połowie października 1939 r., na skutek haniebnego układu ${ }^{76}$ pomiędzy Ribbentropem ${ }^{77}$ a Mołotowem ${ }^{78}$, którzy przekreślili oba pakty o wzajemnej nieagresji pomiędzy Niemcami i Rosją a Polską ${ }^{79}$, przez jednoczesne zaatakowanie nas od zachodu i wschodu w czasie kiedyśmy tak bardzo krwawili w walce z Hitlerem. Ta wspólna napaść, przez Polskę niczym nie sprowokowana, najlepiej chyba i po wieczne czasy charakteryzuje wartość moralną i metody obu naszych wrogów, i trudno nawet byłoby określić, który z nich jest gorszy. Aby móc się im przeciwstawić potrzebujemy innej organizacji Europy, aniżeli ta jaką jest ta dzisiejsza. I Europa stworzona przez Clemenceau ${ }^{80} \mathrm{w}$ Traktacie

\footnotetext{
${ }^{76}$ Mowa tu o dwóch układach. Na mocy pierwszego z 23 sierpnia 1939 r. zwanym Paktem Ribbentrop-Mołotow (Hitler-Stalin) doszło do zawarcia tajnego porozumienia dotyczącego podziału stref wpływów w Europie Wschodniej pomiędzy III Rzeszą a Związkiem Radzieckim. Drugim był układ pomiędzy Związkiem Radzieckim a Litwą, na mocy którego 10 października 1939 r. Moskwa przekazała Litwinom Wileńszczyznę.

77 Joachim von Ribbentrop (1893-1946), minister spraw zagranicznych III Rzeszy w 1. 1938-1945.

${ }_{78}$ Wiaczesław Mołotow (1890-1986), działacz komunistyczny, polityk, minister spraw zagranicznych Związku Radzieckiego w 1. 1939-1949.

${ }^{79}$ Mowa o polsko-sowieckim pakcie o nieagresji z 25 lipca 1932 r. oraz o polsko-niemieckiej deklaracji o nieagresji z 26 stycznia $1934 \mathrm{r}$.

${ }^{80}$ Georges Clemenceau (1841-1929), francuski polityk, mąż stanu, premier w 1. 1906-1909, $1917-1920$.
} 
Wersalskim jest lepszą aniżeli ta jaką bezprawnie ukonstytuowano, pod naciskiem Sowietów w umowie Jałtańskiej ${ }^{81}$.

W wytworzonych warunkach, Rektor Ehrenkreutz został bardzo prędko aresztowany przez Sowiety i uwięziony (bez żadnych oczywiście ku temu podstaw), a następnie po szeregu miesięcy wypuszczony w takim stanie, że po poprzednio doznanych torturach wnet zmarł (jak twierdzą w dniu 20 lipca 1945 roku) ${ }^{82}$. Padł więc ofiarą w walce narodowej.

III.

Obok zmieniających się tendencji, jakim uległ Uniwersytet Stefana Batorego w związku z różnym jego nakierowaniem przez poszczególnych rektorów, rozwój jego odbywał się jednak w sposób całkiem normalny i niepowstrzymany, i to zarówno na polu przyrostu liczby studentów i poziomu nauczania, jak i wydajności naukowej. Rokrocznie statystyki stwierdzają, że z liczby 547 studentów w roku 1919/20 wzrosła ona do 3110 w roku 1938/39, w tym na Wydział Teologiczny przypadło 132, na Humanistyczny 313, Prawa i Nauk Społecznych 953, Matematyczno-Przyrodniczy 556, Lekarski 736, [Oddział] Farmaceutyczny 96, Sztuk Pięknych 85, a Rolniczy (w ostatnim roku istnienia) 229. Katedr, zakładów i klinik liczył uniwersytet w ostatnim roku 104, profesorów miał 84, zastępców profesorów 39, pomocniczych zaś sił naukowych 245. Biblioteka zawierała około 500.000 tomów, a liczba ogłoszonych prac, odczytów, referatów i drobnych przyczynków sięgała przeszło 7000.

Podział narodowościowy studentów, zarówno w ostatnim roku jak i poprzednio, odznaczał się wciąż naturalnie stałą przewagą Polaków. W roku 1938/39 było ich 2173, liczba Żydów doszła do 432, czyli do - 20\%, podczas gdy inne narodowości były reprezentowane znikomymi liczbami, zwłaszcza Litwinów i Łotyszów.

Duża ilość elementu żydowskiego dawała częsty powód do przykrych starć (jak np. odmowy sąsiadowania przy wspólnym stole ćwiczeń), a nawet nieraz krwawych walk, wypływających z odmiennych mentalności, często lepszego sytuowania materialnego, może również ich większej pracowitości, co wszystko razem świadczyło o antysemityzmie, rozpowszechnionym od czasów chyba najdawniejszych ich wymuszonej diaspory na całym świecie.

Starcia te zrodziły się najpierw [wykreślone słowo nieczytelne] w związku i wokoło tzw. „sprawy trupiej”, czyli odmowa społeczeństwa żydowskiego dostarczania ich zwłok do prosektorium anatomicznego na Wydziale Lekarskim (na co jakoby nie pozwalała ich religia), tak iż to było obsługiwane wyłącznie przez chrześcijan i doprowadziło do szeregu bijatyk, strajków i kompletnego rozdwojenia narodowościowego wśród studenterii, a nawet przypadkowego zabójstwa jednego ze studentów Polaków, co było źródłem nie tylko nowych scysji ale i ulicznych manifestacji ludności chrześcijańskiej Wilna. Jednak, wobec niemożności znalezienia jakiegoś sensownego i skutecznego wyjścia z tej trwałej a pożałowania godnej sytuacji, całość sprawy, w przededniu drugiej wojny światowej i coraz to wzmagających się gróźb Hitlera, jakoś przycichła.

Mimo to, Uniwersytet jako całość pozostawał wierny swym starodawnym tradycjom i pracował jak tylko mógł na polu naukowym, jak również w Kołach i Klubach Studenc-

${ }^{81}$ Mowa o konferencji przywódców Stanów Zjednoczonych, Wielkiej Brytanii i Związku Radzieckiego, która miała miejsce w Jałcie 4-11 lutego 1945 r. Jednym z jej postanowień było oddanie Polski w radziecką strefę wpływów, ustalenie nowych granic i przemieszczenie ludności.

${ }^{82}$ S. Ehrenkreutz zmarł w więzieniu na Łukiszkach 21 lipca 1945 r. 
kich, które uruchomiły piękne wydawnictwa roczników „Alma Mater Vilnensis" ${ }^{\text {"33 }}$, a tymi gorąco opiekował się zawsze dbały i niezmordowany Ferdynand Ruszczyc ${ }^{84}$.

Na poszczególnych Wydziałach wyróżniali się, jak i poprzednio, następujący profesorowie:

Na Wydziale Teologicznym z 9 profesorów: Bronisław Żongołłowicz zakreśleniem szerokich horyzontów wiążących w jedno myśl i wiarę, prof. Nowicki ${ }^{85}$ dokładną znajomością Starego Testamentu, który mógł czytać w pierwotnym jego brzmieniu, ks.

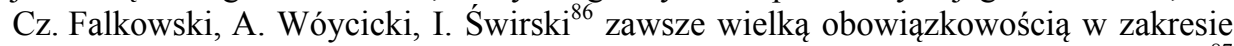
reprezentowanych przez nich dyscyplin. Inni, może mniej wybitni, jak ks. L. Puciata ${ }^{87}$ walczył o pojednanie wyznań chrześcijańskich, ks. M. Klepacz ${ }^{88}$ rozbudowywał podstawy filozofii chrześcijańskiej, ks. W. Meysztowicz ${ }^{89}$ zaś był zaangażowany w śmiałą walkę o ścisłą interpretację prawa kanonicznego.

Wydział Humanistyczny dość bogato był reprezentowany w zakresie językoznawstwa porównawczego przez bardzo pracowitego prof. J. Otrębskiego ${ }^{90}$, w zakresie filozofii wzorem ścisłości był lwowianin prof. T. Czeżowski ${ }^{91}$ oraz Bogumił Jasinowski $^{92}$, mający duże ambicje co do znajomości filozofii starożytnej, zwłaszcza greckiej, choć wykazywał również zainteresowania we wszystkich możliwych dziedzinach. Z zakresu filologii klasycznej, Rzym reprezentował prof. Jan Oko ${ }^{93}$, świat Grecki zaś Stefan Srebrny ${ }^{94}$ (uczeń jednego z największych klasyków prof. Tadeusza Zielińskiego wpierw z Petersburga, następnie z Warszawy). Historię Polski z talentem wykładał bardzo wyrozumiały i zacny Stanisław Kościałkowski ${ }^{95}$, równocześnie gorący jak i kompletnie bezpartyjny patriota, który jednak jeden z pierwszych został zaaresztowany i wywieziony przez okupantów sowieckich za krąg polarny, ale następnie, na mocy paktu $^{96}$ gen. Sikorskiego ${ }^{97}$ z Rządem sowieckim, zwolniony, udał się do Libanu gdzie opiekował się wywiezioną tam z Persji naszą kilkutysięczną emigracją oraz założył

${ }^{83}$ „Alma Mater Vilnensis” — czasopismo wydawane przez Zrzeszenie Kół Naukowych USB w 1. 1922-1935.

${ }^{84}$ Ferdynand Ruszczyc (1870-1936), malarz, grafik, profesor Szkoły (Akademii) Sztuk Pięknych w Krakowie od 1904 r., profesor malarstwa USB w 1. 1919-1935.

${ }^{85}$ Paweł Nowicki (1888-1980), zastępca profesora i profesor Pisma Św. Starego Testamentu od $1924 \mathrm{r}$.

${ }^{86}$ Ignacy Świrski (1885-1968), ksiądz, profesor Rzymskokatolickiej Akademii Duchownej w Petersburgu, profesor teologii moralnej USB od $1921 \mathrm{r}$.

${ }^{87}$ Leon Puciata (1884-1943), ksiądz, zastępca profesora i profesor teologii dogmatycznej USB od $1923 \mathrm{r}$.

${ }^{88}$ Michał Klepacz (1893-1967), ksiądz, profesor filozofii chrześcijańskiej USB od $1924 \mathrm{r}$.

${ }^{89}$ Walerian Meysztowicz (1893-1982), profesor prawa kanonicznego USB w 1. 1936-1939.

90 Jan Otrębski (1889-1971), zastępca profesora i profesor językoznawstwa indoeuropejskiego i filologii sanskryckiej USB od $1921 \mathrm{r}$.

${ }_{91}$ Tadeusz Czeżowski (1889-1981), profesor filozofii USB od 1923 r.

${ }^{92}$ Bogumił Jasinowski (1883-1969), profesor filozofii USB w 1. 1931-1939.

93 Jan Oko (1875-1946), zastępca profesora i profesor filologii klasycznej od $1920 \mathrm{r}$.

${ }^{94}$ Stefan Srebrny (1890-1962), profesor filologii klasycznej USB od 1924 r.

${ }^{95}$ Stanisław Kościałkowski (1881-1960), zastępca profesora i profesor historii Polski USB od $1921 \mathrm{r}$

${ }^{96}$ Układ Sikorski-Majski podpisany 30 lipca 1941 r. przywracający stosunki dyplomatyczne pomiędzy Polską a Związkiem Radzieckim. W tekście paktu użyto niefortunnego zwrotu o udzieleniu amnestii dla obywateli polskich, faktycznie dla Polaków, pozbawionych wolności, a przebywających na terenie Związku Radzieckiego.

97 Władysław Sikorski (1881-1943), generał, polityk, premier w 1. 1939-1943, Naczelny Wódz w 1. 1939-1943. 
Instytut Polski i wydał kilka tomów tzw. „Teki Bejruckie”, aby następnie wraz z resztą emigracji zostać przeniesionym do Anglii, gdzie zmarł.

Historię nowożytną (Litwa i Ruś) wykładał prof. J. Iwaszkiewicz ${ }^{98}$ z Mińszczyzny, historię średniowieczną S. Zajączkowski ${ }^{99}$, historię zaś Europy Wschodniej H. Łowmiański ${ }^{100}$. Historię literatury polskiej reprezentowali kolejno St. Pigoń, a następnie Manfred Kridl ${ }^{101}$ oraz Konrad Górski ${ }^{102}$. Zasługują na wzmiankę ponadto profesor archeologii klasycznej R. Gostkowski ${ }^{103}$, etnologii zaś i etnografii prof. K. Moszyński $^{104}$, filologii zaś słowiańskiej prof. Erwin Koschmieder ${ }^{105}$ ze Śląska. Ten ostatni, zaangażowany na Uniwersytet Stefana Batorego, z pewnością w jak najlepszych zamiarach [wykreślone: przez prof. Cezarię Baudin de Courtenay Jędrzejewiczową ${ }^{106} \mathrm{i}$ jej męża ministra J. Jędrzejewicza] przyznał się na samym początku wojny hitlerowskiej [wykreślone: o ile nawet nie przed nią] do uprawiania szpiegostwa na rzecz Niemiec i ze złośliwym tryumfem nadesłał swą dymisję, zwracając również swą legitymację profesorską. Również znani byli z pośród docentów i zastępców profesora, jako bardzo czynni: Ryszard Mienicki ${ }^{107}$ - historyk, Stanisław Cywiński ${ }^{108}$ z literatury polskiej, wywieziony przez Sowiety, jako gorący patriota Polski do Wiatki i tam zamordowany na początku 1941 roku. Wreszcie H. Elsenberg ${ }^{109}$ specjalizował się w zakresie filozofii. Ogólem więc wydział Humanistyczny, z pewnością jak najwyraźniej [wykreślone słowo nieczytelne] reprezentujący ideologię dawniejszego Uniwersytetu Wileńskiego, liczył 14 profesorów, 3 zastępców profesora, 2 docentów oraz 24 wykładających.

Niemniej wiernym ideologii dawnego Uniwersytetu Wileńskiego był Wydział Prawa i Nauk Społecznych reprezentowany przez bardzo obowiązkowych i dociekliwych erudytów, jak Franciszek Bossowski ${ }^{110} \mathrm{z}$ prawa rzymskiego, wyznawca ustroju monarchicznego nawet dla Polski, zawsze zrównoważony i troskliwie analizujący Eugeniusz Waśkowski $^{111}$ (postępowanie prawa cywilnego), zawsze uśmiechnięty ks. prof. Bolesław Wilanowski ${ }^{12} \mathrm{z}$ prawa kościelnego, dość ponury Bronisław Wróblewski ${ }^{113} \mathrm{z}$ prawa i postę-

${ }^{98}$ Janusz Iwaszkiewicz (1879-1944), profesor historii nowożytnej USB od $1930 \mathrm{r}$.

99 Stanisław Zajączkowski (1890-1977), profesor historii średniowiecznej i nauk pomocniczych historii USB od $1932 \mathrm{r}$.

${ }^{100}$ Henryk Łowmiański (1898-1984), profesor historii Europy Wschodniej USB od 1933 r.

${ }^{101}$ Manfred Kridl (1882-1957), profesor historii literatury polskiej USB od $1932 \mathrm{r}$.

${ }^{102}$ Konrad Górski (1895-1990), profesor historii literatury polskiej USB od 1934 r.

103 Rajmund Gostkowski (1885-1966), zastępca profesora i profesor filologii klasycznej USB od $1929 \mathrm{r}$

${ }^{104}$ Kazimierz Moszyński (1887-1959), profesor etnologii i etnografii USB w 1. 1935-1939.

${ }^{105}$ Erwin Koschmieder (1896-1977), profesor filologii słowiańskiej USB od 1931 r.

${ }^{106}$ Cezaria Jędrzejewicz (Jędrzejewiczowa z domu Baudouin de Courthenay (1885-1967), profesor etnografii i etnologii USB w 1. 1927-1935, profesor etnografii i etnologii UW od 1935 r.

${ }^{107}$ Ryszard Mienicki (1886-1956), docent historii Polski USB od 1923 r., profesor tytularny USB.

${ }^{108}$ Stanisław Cywiński (1888-1941), docent historii literatury polskiej XIX i XX wieku USB od $1929 \mathrm{r}$.

${ }^{109}$ Henryk Elzenberg (1887-1967), docent filozofii USB w 1. 1936-1939.

110 Franciszek Bossowski (1879-1940), zastępca profesora i profesor prawa rzymskiego USB w 1. 1920-1938.

${ }^{111}$ Eugeniusz Waśkowski (1866-1942), profesor prawa cywilnego USB od 1924 r.

112 Bolesław Wilanowski (1885-1952), zastępca profesora i profesor prawa kanonicznego na Wydziale Teologicznym USB w 1. 1920-1929, profesor prawa kanonicznego na Wydziale Prawa i Nauk Społecznych USB od 1929 r.

113 Bronisław Wróblewski (1888-1941), zastępca profesora i profesor prawa i procedury karnej USB od $1921 \mathrm{r}$. 
powania karnego, który niewątpliwie przyczynił się w roku 1933/34 do zwinięcia katedry zawsze doń krytycznie usposobionego prof. Stefana Glasera, oraz przez innych bardziej zaangażowanych $\mathrm{w}$ ówczesną politykę jak Wacław Komarnicki ${ }^{114}$ (prawo państwowe), ostatni z wyboru Rektor Stefan Ehrenkreutz (z historii prawa polskiego i litewskiego), Jerzy Panejko ${ }^{115}$ (prawo administracyjne), M. Gutkowski ${ }^{116} \mathrm{z}$ prawa skarbowego, rozstrzelany bez żadnych powodów w dniu 17 września 1943 roku przez hitlerowców ,jako zakładnik", oraz mniej wzięci: prof. A. Chełmoński ${ }^{117}$ (prawo handlowe) i Iwo Jawor$\mathrm{ski}^{118}$ (historia prawa na Zachodzie Europy).

W pierwszych latach Uniwersytetu wykładali na tym wydziale jako zastępcy profesorów wybitni adwokaci: Zygmunt Jundziłł ${ }^{119}$ (prawo cywilne rosyjskie) i Kazimierz Petrusewicz ${ }^{120}$. Z docentów wyróżniali się, jako bardziej znani, Stanisław Swianiewicz $^{121}$, Michał Król ${ }^{122}$, Wiktor Sukiennicki ${ }^{123}$, Witold Świda ${ }^{124}$, Andrzej Mycielski ${ }^{125}$, Seweryn Wysłouch $^{126}$, Jan Adamus ${ }^{127}$, Jakub Sawicki ${ }^{128}$.

Mało zmieniały się w ciągu drugiego dziesięciolecia Uniwersytetu Stefana Batorego składy Wydziałów Matematyczno-Przyrodniczego i Lekarskiego.

Oba te wydziały szczerze i uczciwie pragnęły rozwijać wiedzę czystą w ujęciu z pewnością przekazanym przez dawniejszy Uniwersytet, a w szczególności przez Jana $^{129}$ i Jędrzeja Śniadeckich ${ }^{130}$, przez Poczobuta-Odlanickiego ${ }^{131}$, przez Jundziłła ${ }^{132}$,

${ }^{114}$ Wacław Komarnicki (1891-1954), profesor prawa państwowego i nauki o państwie USB od $1921 \mathrm{r}$

${ }^{115}$ Jerzy Panejko (1886-1973), profesor prawa administracyjnego USB od 1928 r.

116 Mieczysław Gutkowski (1893-1943), zastępca profesora i profesor prawa skarbowego i nauki skarbowości USB od $1921 \mathrm{r}$.

117 Adam Chełmoński (1890-1959), zastępca profesora i profesor prawa handlowego i wekslowego USB od $1922 \mathrm{r}$.

${ }^{118}$ Iwo Jaworski (1889-1959), zastępca profesora i profesor historii prawa na Zachodzie Europy od $1922 \mathrm{r}$.

${ }^{119}$ Zygmunt Jundziłł (1880-1953), zastępca profesora prawa cywilnego USB od $1922 \mathrm{r}$.

${ }^{120}$ Kazimierz Petrusewicz senior (1872-1949), zastępca profesora procedury cywilnej USB od $1922 \mathrm{r}$.

${ }^{121}$ Stanisław Swianiewicz (1899-1997), profesor ekonomii politycznej USB w 1. 1938-1939.

${ }^{122}$ Michał Król (1900-1943), docent prawa narodów USB od $1931 \mathrm{r}$.

${ }^{123}$ Wiktor Sukiennicki (1901-1983), docent prawa międzynarodowego USB od 1929 r., zastępca profesora teorii i filozofii prawa USB.

${ }^{124}$ Witold Świda (1899-1989), docent prawa karnego USB od 1933 r.

${ }^{125}$ Andrzej Mycielski (1900-1993), docent prawa państwowego i nauki o państwie USB od $1933 \mathrm{r}$.

${ }^{126}$ Seweryn Wysłouch (1900-1968), docent historii dawnego prawa litewskiego USB od $1937 \mathrm{r}$

${ }^{127}$ Jan Adamus (1896-1962), docent historii dawnego prawa polskiego i litewskiego USB od $1934 \mathrm{r}$

128 Jakub Sawicki (1899-1979), docent prawa kościelnego USB od 1937 r.

129 Jan Śniadecki (1756-1830), astronom, matematyk, filozof, profesor Szkoły Głównej Koronnej od $1781 \mathrm{r}$.

${ }^{130}$ Jędrzej Śniadecki (1768-1838), profesor chemii i medycyny Szkoły Głównej Litewskiej do 1795 r., następnie Szkoły Głównej Wileńskiej, od 1803 r. Cesarskiego Uniwersytetu Wileńskiego, od 1832 r. Akademii Medyko-Chirurgicznej w Wilnie.

131 Marcin Poczobut-Odlanicki (1728-1810), profesor matematyki i astronomii Szkoły Głównej Litewskiej, od 1795 r. Szkoły Głównej Wileńskiej, rektor w 1. 1780-1799.

${ }^{132}$ Stanisław Jundziłł (1761-1847), suplent i profesor historii naturalnej Szkoły Głównej Wileńskiej od 1797 r., od 1803 r. Cesarskiego Uniwersytetu Wileńskiego. 
Bojanusa ${ }^{133} \mathrm{i}$ innych... Wszystkie normalnie przepisane katedry były obsadzone i profesorowie, którzy je zajmowali różnili się pomiędzy sobą zarówno od początku przyjętymi zwyczajami lub zachowaniem się, jak i następnie istniejącymi różnicami ich charakterów, czy też wciąż odnawiających się kłótni lub też wiązaniem się w pewne ugrupowania. Tak więc na katedrach matematyki widziało się dobrodusznego, lecz z miłości do matematyki często roztargniętego prof. Juliusza Rudnickiego ${ }^{134}$, bardzo lewicowo usposobionego Antoniego Zygmunda ${ }^{135}$, ale ceniącego mimo to matematykę więcej aniżeli politykę, tak iż przy pierwszej nadarzającej się sposobności wyemigrował on do Stanów Zjednoczonych i tam już pozostał; i wreszcie dużo więcej zakłopotanego i może mniej pewnego siebie, a przy tym źle wykładającego Stefana Kempistego ${ }^{136}$, który wtrącony przez Sowiety do więzienia w roku 1940, miał się tam powiesić.

Na katedrze astronomii i Obserwatorium Astronomicznego (które zostało wzniesione pod Zakretem), widziało się zawsze pod wąsem uśmiechającego się Władysława Dziewulskiego w otoczeniu wiernie mu oddanych i [wykreślone słowo nieczytelne] nieodstępnych dr Wilhelminy Iwanowskiej ${ }^{137}$ oraz dra Stanisława Szeligowskiego ${ }^{138}$. Fama głosiła, że ci ostatni współzawodniczyli pomiędzy sobą i dr Szeligowski miał mieć żal do swego kierownika za wyróżnienie i lepszą ocenę dr Iwanowskiej. Tuż obok współpracował z astronomią profesor meteorologii Kazimierz Jantzen ${ }^{139}$, zawsze bardzo życzliwy i uczynny, choć obciążony ciężką chorobą nerwową, która czyniła go kulawym.

W jak najlepszej z astronomią zgodzie pozostawali profesorowie fizyki doświadczalnej, z których jedna $\mathrm{z}$ katedr była obsadzona przez brata astronoma, prof. Wacława Dziewulskiego $^{140}$, druga zaś przez Józefa Patkowskiego ${ }^{141}$, który zdaniem moim nie wykazał się poważniejszym dorobkiem naukowym, ale pierwszy z wymienionych bywał wciąż chory, a drugi często zajmował [wykreślone 2 słowa nieczytelne] rozmaite stanowiska administracyjne i robił wrażenie przebiegłego i stronniczego w swych zarządzeniach. Prof. Patkowski zginął podczas bombardowania Warszawy, ugodzony 21 VIII1942 r. granatem podczas ukrywania się w bramie wjazdowej domu. Do tej dwójki, dołączyli jeszcze na katedrze fizyki teoretycznej profesorowie: wpierw Jan Weyssenhof $^{i 2}$, a następnie, po przejściu tegoż na Uniwersytet Jagielloński, dr Szczepan Szczeniowski ${ }^{143}$ — naukowiec o dalekich horyzontach, przy tym niezależny i unikający angażowania się w jakiekolwiek przyjaźnie czy stosunki osobiste. Zarówno astronomowie jak i fizycy tworzyli zgraną grupkę, która często narzucała $\mathrm{Na}$ Wydziale swoje punkty widzenia innym.

${ }^{133}$ Ludwik Bojanus (1776-1827), niemiecki biolog, lekarz, przy Cesarskim Uniwersytecie Wileńskim założył w 1823 r. Instytut Praktycznej Weterynarii.

${ }^{134}$ Juliusz Rudnicki (1881-1948), profesor matematyki USB od 1923 r.

${ }^{135}$ Antoni Zygmund (1900-1992), profesor matematyki USB od $1930 \mathrm{r}$.

${ }^{136}$ Stefan Kempisty (1892-1940), zastepca profesora i profesor matematyki USB od $1920 \mathrm{r}$.

${ }^{137}$ Wilhelmina Iwanowska (1905-1999), docent astronomii USB od $1937 \mathrm{r}$.

${ }^{138}$ Stanisław Szeligowski (1887-1966), doktor filozofii (astronomia) USB, adiunkt przy katedrze astronomii (Obserwatorium Astronomiczne) od $1923 \mathrm{r}$.

${ }^{139}$ Kazimierz Jantzen (1885-1940), profesor meteorologii USB od $1924 \mathrm{r}$.

${ }^{140}$ Wacław Dziewulski (1882-1938) profesor fizyki USB w 1. 1921-1938.

141 Józef Patkowski (1887-1942), profesor fizyki doświadczalnej USB od 1919 r.

${ }^{142}$ Jan Weysenhoff (1889-1972), profesor fizyki teoretycznej USB w 1. 1921-1935, profesor fizyki teoretycznej UJ od $1935 \mathrm{r}$.

${ }^{143}$ Szczepan Szczeniowski (1898-1979), profesor fizyki teoretycznej USB w 1. 1937-1939. 
Chemicy natomiast nie trzymali się razem: prof. Marian Hłasko ${ }^{144}$ na chemii nieograniczonej wywodził się z kresów, był więc dzielnicowo odmienny od prof. Kazimierza Sławińskiego ${ }^{145}$, warszawianina i farmaceuty na chemii organicznej, z długą i okazałą brodą i zawsze wysokiego o sobie samym mniemania, apodyktycznie narzucającego swój punkt widzenia innym, czego zresztą najczęściej nie brano pod uwagę, śmiejąc się zeń po cichu. Nie było też zgody pomiędzy obu tymi chemikami: Marian Hłasko, choć może mniej ceniony, miał dużo większe poczucie obywatelskie i w ostatnich latach istnienia USB zapisał mu w swym testamencie mająteczek na Wileńszczyźnie, podczas zaś inwazji Sowieckiej w roku 1939/41 czuł się tak przygnębionym i rozstrojonym nerwowo, że któregoś dnia, jak twierdzą z racji jakiegoś drobnego nieporozumienia ze służbą, skończył samobójstwem przez zażycie trucizny.

Świadczy to wymownie o ówczesnej sytuacji Polaków i o przeżywanych wówczas nastrojach beznadziejności w Wilnie.

Trzecim chemikiem był dużo poważniejszy od obu poprzednich, zawsze zrównoważony, uprzejmy i bardzo życzliwy profesor chemii Edward Bekier ${ }^{146}$, podobnie jak $\mathrm{i}$ jego adiunkt docent dr Antoni Basiński ${ }^{147}$, późniejszy chemik Uniwersytetu im. Kopernika w Toruniu. Wreszcie obsadę katedr chemii [wykreślone słowo nieczytelne] uzupełniał inż. Witold Kraszewski ${ }^{148}$, profesor chemii technicznej, człowiek dużej wiedzy i zawsze bardzo zrównoważony, nigdy nie zaangażowany, nawet niewzruszenie obojętny na wszystko co się wokół niego działo.

Katedrę geologii, po profesorze Rydzewskim ${ }^{149}$, zajmował prof. Edward Passendorfer ${ }^{150}$, który z pewnością miał szczere zainteresowania do tej branży naukowej, ale zdaje się mi, żadnego dorobku po sobie nie zostawił, ani też Wileńszczyzną się nie interesował, wywodząc się z Górnego Śląska.

Katedrę mineralogii i petrografii, po śmierci prof. Józefa Łukaszewicza ${ }^{151}$ (wszechstronnego erudyty, syntetyka, światłego i szlachetnego naukowca, a jednocześnie dawniejszego dożywotniego więźnia ze Schlisselburga w Petersbusgu, zwolnionego jednak podczas rewolucji 1905 roku, a który z pewnością przerastał poziomem cały wydział, ale czuł się obco w tym środowisku), zajmował prof. Stanisław Małkowski ${ }^{152}$, którego działalność niczym się nie zaznaczała.

Katedrę geografii zajmował głośny i buńczuczny, ale raczej mało krytyczny prof. Mieczysław Limanowski ${ }^{153}$ (syn znanego działacza społecznego), którego traktowano raczej jako kaznodzieję czy aktora bardzo wszelkiej teatralności oddanego, ale mało poważnego w swych studiach uniwersyteckich. Był to jednak równocześnie człowiek uczuciowy i patriota prawdziwy, a gdy Polskę spotkała we wrześniu 1939 r. wspólna napaść Niemców i Rosjan, to można było go widzieć samotnie i smutnie siedzącego a nawet załzawionego na ławkach ogrodów lub ulicznych i ciężko przeżywającego nasz wspólny los niedoli. Mówiono, że tracił zmysły i stał się pomylony.

${ }^{144}$ Marian Hłasko (1889-1940 lub 1941), zastępca profesora i profesor chemii nieorganicznej USB od $1921 \mathrm{r}$.

\footnotetext{
${ }^{145}$ Kazimierz Sławiński (1870-1941), profesor chemii organicznej USB w 1. 1920-1936.

${ }^{146}$ Edward Bekier (1883-1945), profesor chemii fizycznej USB od $1922 \mathrm{r}$.

${ }^{147}$ Antoni Basiński (1905-1990), docent chemii fizycznej USB od $1936 \mathrm{r}$.

${ }^{148}$ Witold Kraszewski (1874-1943), profesor chemii teoretycznej USB w 1. 1924-1938.

${ }^{149}$ Bronisław Rydzewski (1884-1945), profesor geologii USB w 1. 1920-1933.

${ }^{150}$ Edward Passendorfer (1894-1984), profesor geologii USB od $1936 \mathrm{r}$.

${ }^{151}$ Józef Łukaszewicz (1863-1928), profesor geologii USB w 1. 1919-1928.

${ }^{152}$ Stanisław Małkowski (1889-1962), profesor mineralogii i petrografii USB od 1934 r.

${ }^{153}$ Mieczysław Limanowski (1876-1948), profesor geografii fizycznej USB od 1927 r.
} 
Pomiędzy kierownikami katedr botanicznych panowała najzupełniejsza zgoda. Zajmowali je prof. Piotr Wiśniewski ${ }^{154}$, dość podejrzliwy, lękliwy i na ogół mało wydajny, ale za to zawsze nieposzlakowanie prawy, oraz prof. Józef Trzebiński ${ }^{155}$, głęboko oddany roślinoznawstwu w ogóle i zawsze bardzo uprzejmy, choć nieprawdopodobnie roztargniony i tak krótkowzroczny, że jak stwierdzono, miał nie poznawać własnej żony (bardzo sympatycznej, prawdziwej Litwinki) przy spotkaniach z nią na ulicy.

W zakładach zoologicznych za to panował wciąż nastrój napięcia i kłótni pomiędzy prof. Janem Prüfferem ${ }^{156}$, człowiekiem bez głębszych uzdolnień, ale za to ogromnie pracowitym, zwłaszcza a raczej wyłącznie w zakresie swej specjalności - motyloznawstwa i szkodników roślinnych a Władysławem Szeligą-Mierzejewskim ${ }^{157}$ (z wyspy Esel w Estonii, na Bałtyku), który choć miał dużo większe zdolności, ale wydawał się być leniuchem i, będąc na katedrze anatomii porównawczej wolał zajmować się systematyką zwierząt bezkręgowych oraz płazów i gadów. Obaj nie posiadali wcale habilitacji, a choć osobiście pokłóceni, byli dalecy od jakiejkolwiek polityki. Co prawda, prof. Mierzejewski, przyjął w ciągu toczącej się wojny stanowisko docenta w niemieckim podówczas Uniwersytecie Poznańskim, zadeklarował się jako „Volksdeutche” i uciekając dalej na Zachód wraz z Niemcami (był zresztą ożeniony z Niemką) nigdy już do Polski nie powrócił. Znając go, należałoby jednak sądzić, że był to najprawdopodobniej jedynie krok zabezpieczający mu sytuację materialną, nie zaś jakieś odstępstwo narodowe, do czego nie miałby żadnych podstaw osobistych.

Prawdziwe polityczne tendencje w zakresie katedr zoologicznych wniósł dopiero prof. Jan Dembowski ${ }^{158}$ na [wykreślony fragment tekstu] podstępnie przeniesionej katedrze biologii ogólnej z Wydziału Lekarskiego na Wydział [Matematyczno-]Przyrodniczy w roku 1934, o czym poprzednio była mowa. Był on wyznawcą i członkiem partii komunistycznej i takimiż ludźmi się otaczał, co o tyle może być pożałowania godnym, że był to bardzo zdolny zoolog, który poświęcał się głównie psychologii porównawczej zwierząt niższych, głównie wymoczków, nie dokonując jednak żadnych poważniejszych odkryć. Nie znosił żadnych sprzeciwów i przerywał wszelką dyskusję, o ile nie rozwijała się ona po jego myśli. [wykreślone: Są to zresztą objawy, które spotykają się również u ludzi nic z polityką nie mających do czynienia] Co mogło i powinno dziwić dużo bardziej, jest fakt, że będąc niezaprzeczalnie Polakiem, unikał, nawet w okresie swych studiów uniwersyteckich w Rosji, rozmowy w języku polskim w obecności Rosjan, [wykreślone: zmieniając] przechodząc je na język rosyjski.

Związane z Wydziałem Matematyczno-Przyrodniczym Studium Rolnicze w ciągu kilku lat z kolei przeżywało swe bóle porodowe rozporządzając jedynie terenem niewielkiego folwarku Zakręt, oraz raczej niedochodową i wciąż zagmatwaną w sporach prawnych Fundacją Żemłosławską ${ }^{159} \mathrm{hr}$. Janiny Umiastowskiej ${ }^{160}$. Długo tonęło w waśniach czy sporach osobistych, jak np. zerwanie stosunków pomiędzy kierownikiem

${ }^{154}$ Piotr Wiśniewski (1881-1971), profesor botaniki USB od 1919 r.

155 Józef Trzebiński (1867-1941), profesor botaniki USB w 1. 1924-1937.

${ }^{156}$ Jan Prüffer (1890-1959), zastępca profesora i profesor zoologii USB od $1922 \mathrm{r}$.

157 Władysław Szeliga-Mierzeyewski (1882-1959), profesor anatomii porównawczej USB od $1928 \mathrm{r}$

${ }^{158}$ Jan Dembowski (1889-1963), profesor biologii ogólnej USB od 1934 r.

${ }^{159}$ Fundacja Żemłosławska - na podstawie aktu darowizny z 6 marca 1922 r. majątek Żemłosław został przekazany USB i powołano Fundację Naukową imienia Władysława i Janiny Umiastowskich.

${ }^{160}$ Janina Umiastowska z domu Sadowska (1860-1941), żona Władysława Umiastowskiego, założycielka Fundacji Rzymskiej (Fondazione Romana Marchesa J.S. Umiastowska). 
tego Studium prof. Kazimierzem Rogoyskim ${ }^{161}$ a prof. Władysławem Zawadzkim ${ }^{162}$, byłym choć nieudanym ministrem skarbu. Następnie gdy Studium zostało przekształcone na Wydział Rolniczy w roku 1938, był on reprezentowany raczej przez rolników praktyków, którzy dość dalecy byli od [wykreślono fragment tekstu] zagadnień naukowych. Zresztą tacy profesorowie, jak inż. Wacław Łastowski ${ }^{163}$, omówiony już poprzednio Witold Staniewicz, prof. fizjologii zwierząt i nauki żywienia Edmund Lelesz $^{164}$, prof. uprawy roli, Janusz Jagmin ${ }^{165}$, prof. od hodowli zwierząt Zygmunt Jawor$\mathrm{ski}^{166} \mathrm{i}$ kilku innych, $\mathrm{z}$ pewnością $\mathrm{w}$ rzetelny sposób planowali swą pracę nad podniesieniem rolnictwa na Wileńszczyźnie, ale nadzieje ich zostały udaremnione i unicestwione przez wojnę.

Dużo większych [wykreślone słowo nieczytelne] wstrząsów jakie przeżył Wydział Lekarski w pierwszym dziesięcioleciu swego istnienia, jak m.in.: 1) ustąpienie z katedry histologii i embriologii prof. Jerzego Aleksandrowicza ${ }^{167}$, [wykreślone: a to $\mathrm{z}$ racji tylko minimalne załatwionego jego protestu przeciw — reszta nieczytelna]; 2) analogiczne chociaż o wiele bardziej głośne ustąpienie zamerykanizowanego, a przez to bardziej zdyscyplinowanego prof. Juliusza Retingera ${ }^{168} \mathrm{z}$ katedry chemii fizjologicznej, [wykreślone: a to na skutek nieudowodnionych zarzutów, wysuniętych przez niego przeciw Dziekanowi Zenonowi Orłowskiemu, jakoby ten miał przyjmować łapówki od Żydów przy przyjmowaniu ich na Wydział Lekarski (które podlegało swego rodzaju nieoficjalnemu numerus clausus). Zarzuty te nie zostały przez sądownie przeprowadzone dochodzenie potwierdzone i w swej istocie były więcej niż wątpliwe, ale zmusiły one prof. Retingera do złożenia swej dymisji i przeniesienia się do Krakowa (gdzie otworzył on Laboratorium Analiz Lekarskich, piękna zaś żona jego miała dorabiać wyrobem i sprzedażą kosmetyków), ale całe to przedsięwzięcie prędko bardzo smutno się skończyło i pani Retingerowa jakoś nie znalazła miru wśród społeczeństwa krakowskiego i odjechała do Ameryki, biedny i opuszczony mąż jej wówczas skończył samobójstwem przez zażycie trucizny, dowodząc tym razem raz jeszcze tragizmu własnego niedopasowania do warunków panujących wówczas w Polsce], 3) [wykreślony fragment nieczytelny] przeniesienie w stan nieczynny 3 profesorów, Zenona Orłowskiego, Stanisława Władyczkę i Jana Wilczyńskiego ${ }^{169}$ w roku 1934, o czym poprzednio była mowa). Po tych wstrząsach zapanowała [wykreślone: na wydziale] względna zgodność wśród pozostałych profesorów tego wydziału, którzy przestali być podzieleni na odmienne obozy polityczne względnie na ich rozmaite pochodzenie dzielnicowe. Dało im to możność spokojnej pracy na swych stanowiskach, chociaż wielu z nich przeszło na emeryturę, i następnie bardzo prędko zmarło, a mianowicie zawsze milczący i pracowity bakteriolog dr Teofil Gryglewicz ${ }^{170}$; wielki erudyta, matematyk i higienista prof.

${ }^{161}$ Kazimierz Rogoyski (1870-1940), profesor uprawy roli i roślin USB w 1. 1924-1927.

${ }^{162}$ Władysław Zawadzki (1885-1939), profesor ekonomii politycznej USB w 1. 1919-1931.

163 Wacław Łastowski (1880-1954), profesor szczegółowej uprawy roli i roślin USB od $1929 \mathrm{r}$

${ }^{164}$ Edmund Lelesz (1886-1963), profesor fizjologii zwierząt i nauki żywienia USB od $1930 \mathrm{r}$.

165 Janusz Jagmin (1896-1948), zastępca profesora i profesor ogólnej uprawy roli i roślin USB od $1931 \mathrm{r}$.

${ }^{166}$ Zygmunt Jaworski (1872-1952), profesor hodowli zwierząt USB w 1. 1938-1939.

167 Jerzy Aleksandrowicz (1886-1970), profesor anatomii opisowej USB do $1930 \mathrm{r}$.

${ }^{168}$ Juliusz Retinger (1885-1933), profesor chemii fizjologicznej USB do $1927 \mathrm{r}$.

${ }^{169}$ Autor niniejszych wspomnień.

${ }^{170}$ Teofil Gryglewicz (1873-1936), profesor bakteriologii USB w 1. 1921-1936. 
Kazimierz Karaffa Korbut ${ }^{171}$; fizjolog prof. Marian Eiger $^{172}$, oraz dwóch psychiatrów, wpierw bardzo przenikliwy w swych analizach prof. Rafał Radziwiłłowicz ${ }^{173}$ (zakończył swe życie nagłą śmiercią nagłą, siedząc w wiozącej go do domu dorożce), a następnie poważny badacz architektoniki mózgu prof. Maksymilian Rose ${ }^{174}$; farmakolog Cezary Traczewski ${ }^{175}$; laryngolog Jan Szmurło ${ }^{176}$. Profesor Władysław Jakowicki urodzony w Witebsku, który przeszedłszy z odznaczeniamprzepisowe Curriculum Vitae w klinikach położniczo-ginekologicznych wpierw w Moskwie, a następnie we Lwowie i Warszawie (gdzie się habilitował), Odznaczał się niezachwianym patriotyzmem. Padł on pierwszy (właściwie jedną z pierwszych) ofiar inwazji bolszewickiej na jesieni 1939 roku, kiedy wywieźli go do Rosji na śmierć, gdyż wszelki ślad po nim zaginął. Podobno miał umrzeć w więzieniu po katowaniu, pomimo że żadnej ,przewiny” nawet w zakresie polityki, względem której conajmniej był obojętny, nie dałoby się mu zarzucić. Tak, Wydział Lekarski w ostatnich latach swego istnienia został bardzo odmłodzony, nie cierpiąc już na żadne rozdwojenia wewnętrzne. Nie można by jednak pominąć faktu, że $\mathrm{z}$ pośród nich brutalną ofiarą inwazji hitlerowskiej padł $\mathrm{w}$ żadną politykę niezaangażowany, dociekliwy profesor patologii ogólnej Kazimierz Pelczar ${ }^{177}$ rozstrzelany przez Niemców jako „zakładnik” w dniu 17IX1943 roku, osieracając żonę i kilkoro dzieci.

Na Oddziale Farmaceutycznym wszystko się koncentrowało, jak i w poprzednich latach, wokoło osoby prof. Jana Muszyńskiego ${ }^{178}$, który zresztą był jego zasłużonym twórcą i szczerym opiekunem. Specjalnie przywiązany do hodowli roślin lekarskich, założył pod Zakretem i wspaniale rozwinął ogród roślin lekarskich, a potrafił sobie dobrać profesorów i pracowników naukowych zawsze rzetelnie i wydatnie pracujących, zresztą był jego zasłużonym twórcą i szczerym opiekunem.

Specjalnie przywiązany do hodowli roślin lekarskich, założył pod Zakretem i wspaniale rozwinął ogród roślin lekarskich, a potrafił sobie dobrać profesorów i pracowników naukowych zawsze rzetelnie i wydatnie pracujących [wykreślony fragment tekstu].

Wreszcie, starodawną tradycją przekazany i w swej istocie niezwykły a w dziejach uniwersyteckich rzadki Wydział Sztuk Pięknych w ciągu całego okresu swego istnienia nie przestawał żyć duchem i natchnieniem swego twórcy artysty malarza Ferdynanda Ruszczyca, który otoczył się na polu malarstwa, rzeźby, architektury, zdobnictwa, grafiki i liternictwa, jak niemniej i historii sztuki (którą wykładał Marian Morelowski ${ }^{179}$ ) oddanymi sobie profesorami-artystami, jak Jamontt ${ }^{180}$, Kubicki ${ }^{181}$, Pronaszko ${ }^{182}$, Bałzukiewicz $^{183}$, Kłos $^{184}$ (ten uległ zagadkowemu śmiertelnemu wypadkowi wracając

${ }^{171}$ Kazimierz Karaffa-Korbut (1878-1935), profesor higieny USB w 1. 1922-1935.

${ }^{172}$ Marian Eiger (1873-1939), profesor fizjologii USB w 1. 1922-1939.

${ }^{173}$ Rafał Radziwiłlowicz (1860-1929), profesor kontraktowy psychiatrii USB w 1. 1927-1929.

${ }^{174}$ Maksymilian Rose (1883-1937), profesor neurologii i psychiatrii USB w 1. 1931-1937.

${ }^{175}$ Cezary Traczewski (1866-1941), profesor farmakologii USB od $1921 \mathrm{r}$.

${ }^{176}$ Jan Szmurło (1867-1952), profesor otolaryngologii USB w 1. 1923-1936.

${ }^{177}$ Kazimierz Pelczar (1894-1943), profesor patologii ogólnej USB od 1930 r.

178 Jan Muszyński (1884-1957), profesor farmakognozji i hodowli roślin lekarskich USB od $1921 \mathrm{r}$

${ }^{179}$ Marian Morelowski (1884-1963), profesor historii sztuki USB od $1934 \mathrm{r}$.

${ }^{180}$ Bronisław Jamontt (1886-1957), profesor malarstwa USB od $1937 \mathrm{r}$.

${ }^{181}$ Benedykt Kubicki (1874-1951), profesor malarstwa portretowego USB od $1920 \mathrm{r}$.

${ }^{182}$ Zbigniew Pronaszko (1885-1958), profesor malarstwa monumentalnego USB w 1. 1923 1924.

${ }^{183}$ Bolesław Bałzukiewicz (1879-1935), profesor rzeźby USB w 1. 1919-1935.

${ }^{184}$ Juliusz Kłos (1881-1933), profesor architektury USB w 1. 1920-1933. 
nocą do domu i to ponoć w stanie nietrzeźwym), Sokołowski ${ }^{185}$, Narębski ${ }^{186}{ }^{18}$ Lenart $^{187}$ i inni do których dołączył się bardzo znany w całej Wileńszczyźnie, zdolny i wszechstronny Jan Bułhak ${ }^{188}$, poświęcający się fotografice artystycznej, zapełniając swymi zawsze bardzo udanymi zdjęciami liczne wydawnictwa w całej Polsce.

Sam Ferdynand Ruszczyc, artysta i organizator o niewyczerpanej energii, znany również ze swej zdolności bardzo uciesznego i zawsze interesującego opowiadania, które zbierało zawsze licznych słuchaczy, uległ pod koniec swego życia częściowemu sparaliżowaniu wraz z daleko posuniętą utratą mowy. Ostatnie lata swego życia mimo to potrafił poświęcić kompletnemu uporządkowaniu wszystkich swych zbiorów i pamiątek już we własnym majątku na Wileńszczyźnie, ale całe to prawdziwe muzeum zostało doszczętnie i natychmiast zniszczone przez nadchodzących bolszewików na jesieni 1939 roku, choć twórca jego zmarł już był poprzednio.

Zamykając to krótkie, a nie zawsze wyczerpująco udokumentowane, wspomnienia $\mathrm{z}$ ostatnich lat istnienia Uniwersytetu Stefana Batorego w Wilnie, można by rzec, że pozostał on, na wszystkich wydziałach i na wszystkich polach swej działalności zarówno w zakresie wiedzy jak i sztuki, wierny tradycjom dawniejszego Uniwersytetu Wileńskiego i oddany hasłom szczerego doskonalenia się w patriotycznej służbie ojczyźnie, wiedzy i cnót obywatelskich, stając się w ten sposób faktyczną „Świątynią cnoty i przybytkiem nauk”, „niosąc Koronie i Wielkiemu Księstwu Litewskiemu Miłość, Zgodę i Jedność”, jak to ujmował testament króla Zygmunta $\operatorname{Augusta}^{189}$ z 6 maja 1572 roku. Co prawda zbytecznym byłoby ukrywać czy pomijać milczeniem, że towarzyszyły temu również nieuniknione rozdźwięki, czy powaśnienia osobiste, współzawodnictwa, czy zazdrości, względnie pożałowania godne rozbieżności na polu ówczesnych prądów politycznych, ale w swym najgłębszym i prawdziwym podłożu była to całkiem bezinteresowna droga, którą najlepiej jednak określał napis na starym obserwatorium astronomicznym: [wykreślony fragment tekstu] HINC ITUR AD ASTRA.

Jeżeli następnie, $\mathrm{i}$ to na skutek oburzającej a niczym nie sprowokowanej, $\mathrm{i}$ to wbrew zawartym traktatom o wzajemnej nieagresji — połączonej napaści Hitlera i Sowietów, Litwini mogli zagarnąć Wilno, to jednak z braku odpowiednich sił znaleźli się najpierw w poważnym kłopocie, jak nadal kontynuować istnienie Uniwersytetu Wileńskiego, pozbawionego zarówno profesorów jak i studenterii.

Obecnie z wydanej pod koniec roku 1966 litewskiej książki „Vilniaus Universitetas”, poświęconej obecnemu Uniwersytetowi Wileńskiemu (Wyd. „Mintis”, Vilnius ${ }^{190}$, [wykreślony fragment tekstu] str. 320) można by wnioskować, że trudności w ciągu przeszło 25-lecia są w pewnym stopniu na drodze do przezwyciężenia.

Nie powinno nam zależeć na tym, aby wysiłki ich były udaremnione, gdyż każda, choćby tak niewielka jak litewska narodowość ma niezaprzeczalne prawo do posiadania i rozbudowy swego własnego narodowego uniwersytetu. Pożałowania godnym natomiast i dyskredytującym jest fakt pominięcia przez Litwinów naszego z [wykreślony fragment tekstu] Litwą współistnienia w ciągu prawie 5 stuleci, oraz kompletnego przemilczenia w rzeczywistości nielitewskiego charakteru samego Wilna i całej obszernej Wileńszczy-

\footnotetext{
${ }^{185}$ Ludwik Sokołowski (1882-1936), profesor architektury USB od $1921 \mathrm{r}$.

${ }^{186}$ Stefan Narębski (1892-1966), profesor projektowania i dekoracji wnętrz USB od 1937 r.

187 Bonawentura Lenart (1881-1973), kierownik artystyczny Zakładów Introligatorskiego i Drukarskiego w 1. 1919-1929.

${ }^{188}$ Jan Bułhak (1876-1950), kierownik Zakładu Fotografii Artystycznej od 1919 r.

189 Zygmunt II August (1520-1572), król Polski i wielki książę litewski od 1548 r. Testament król spisał 7 maja 1572 r.

${ }^{190}$ A. Bendzius, J. Kubilius, J. Ziugzda, Vilniaus Universitetas, Vilnius 1966.
} 
zny, i to również w ciągu tychże 5-ciu stuleci, gdzie ludność była przeważnie katolickobiałoruska, z niewielką nigdy 12\% nie przekraczającą domieszką Litwinów, podczas gdy kultura, która się tam krzewiła miała charakter nawet wyłącznie łacińsko-polski. Nawet wszystkie uchwały Sejmików Wileńskich i sąsiednich są zredagowane w tej właśnie mieszaninie językowej i to już od 1600 roku, a zapewne i wcześniej.

Z przytoczonego, w wyżej powołanej książce, spisu wszystkich 73 kolejnych Rektorów tej uczeni, poczynając od roku 1578/79, widać, że nie tylko pierwszym rektorem tej Akademii (będącej w rzeczywistości tworem biskupa Waleriana Protasewicza ${ }^{191}$ ) był Polak sławny ks. Piotr Skarga, ale że i pośród wszystkich dalszych aż do roku 1773 (kiedy Zakon Jezuicki został zlikwidowany ${ }^{192}$ ) wszyscy rektorowie reprezentowali wyłącznie łacińską teologię, a sądząc z brzmienia ich nazwisk z 54 rektorów tego okresu co najmniej ponad 40 musiało być Polakami w służbie Unii Polsko-Litewskiej, z pozostałych zaś 25 rektorów, czyli poczynając od astronoma Marcina Poczobut-Odlanicki w roku 1780, a więc od czasu powstania właściwego Uniwersytetu Wileńskiego, liczba Polaków wynosi 19, z tym że ostatnich 6 z kolei Litwinów przypada dopiero na okres od dokonanej przez Sowiety okupacji w mroku 1939. Na tą samą znikomą liczbę ludności litewskiej miasta Wilna w latach 1939 i 1940 wskazuje również liczna tylko 12.000 paszportów, wydawanych wyłącznie narodowości litewskiej, podczas gdy reszta $\mathrm{z}$ przeszło 200.000 mieszkańców ówczesnego Wilna była prawdziwie polska, względnie żydowska (w jakichś 20\%).

Gdyby więc w przyszłości udało się wytrzebić z natury ludzkiej, i to przede wszystkim z płci męskiej, jako wyłącznie z nią związane, wszystkie instynkty wojowniczości, łupiestwa i wszelkiej zaborczości terytorialnych, które od wieków charakteryzowały obu naszych sąsiadów [wykreślony fragment tekstu] Niemców i Rosjan a w [wykreślony fragment tekstu] następstwie [wykreślono fragment tekstu] cofnać i anulować również wszystkie popełnione na tym polu występki, a w tej liczbie [wykreślony fragment tekstu] uczciwie wykonać Dekret Lenina z września 1918 roku dotyczący „bezpowrotnego anulowania” (,bezpoworotnootmieniajutsia”) wszystkich rozbiorów Polski, [wykreślono fragment tekstu] to i Litwa odzyskałaby wówczas swą niczym nie skrępowaną niepodległość narodową, obecnie powinna by jedynie wstydzić się ciągle trwającym przeinaczaniem prawdziwej historii Rzeczpospolitej, która założyła na jej ziemiach Akademię i Uniwersytet i nigdy prawa do odrodzenia narodowego Litwinom nie odmawiała.

Myślę nawet, że jeżeli samo Wilno, z punktu widzenia czysto historycznego, w dużej mierze musiałoby być uważane za stolicę Wielkiego Księstwa Litewskiego nie tylko przez Litwinów i nie jedynie dla ludności litewskiej, ale przez Polskę i Litwę wspólnie dla ludności mieszanej założoną, to dzisiaj zarówno w naszym jak i litewskim interesie, byłoby otworzyć i rozbudować dwa równoległe Uniwersytety o dwóch językach wykładowych które mogłyby, wydatnie współzawodniczyć i współpracować [wykreślono fragment tekstu] w warunkach kompletnej wolności i swobód obywatelskich w imię wzajemnego porozumienia się i wskrzeszenia dawnej Unii albo nawet większej Federacji, do której mogłyby się z pewnością dołączyć inne Republiki narodowe a to w celu stworzenia Europy bardziej zrównoważonej i niezależnej od dyktanda obcych nam sąsiadów. [wykreślony fragment tekstu]

Marzec 1969 r.

${ }^{191}$ Walerian Protasewicz (ok. 1505-1579), ksiądz, biskup łucki w 1. 1549-1556, wileński w 1. 1556-1579.

${ }^{192}$ Towarzystwo Jezusowe - męski zakon, założony w 1534 r., zlikwidowany w 1773 r., przywrócony w $1814 \mathrm{r}$. 


\section{LITERATURA}

Źródła

Archiwum UMK w Toruniu, Teczka personalna J. Wilczyńskiego, sygn. K-1/335; Teczka personalna L. Kolankowskiego, sygn. K-8/102.

Archiwum Uniwersytetu Jagiellońskiego w Krakowie, WF II 504, Teczka doktorska J. Wilczyńskiego, WF II 508 (Album Doctorum Philosophiae), WF II 121, Teczka habilitacyjna J. Wilczyńskiego, WF II 371 Katalog wydziałowy (dla dziekana) studentów, S II 244A, Katalog główny (dla kwestury) studentów; S II 516, Album Universitatis Jagellonicae Cracoviensis; S II 521, Liber promotionum Universitatis Jagellonicae.

Biblioteka Uniwersytetu Mikołaja Kopernika w Toruniu, Oddział Zbiorów Specjalnych, Dział Rękopisów, Rps 962II, R. Mienicki, „Wspomnienia”.

Instytut Józefa Piłsudskiego w Londynie, Kolekcja 107 B. Podoskiego.

Instytut Polski i Muzeum Generała Sikorskiego w Londynie, Kolekcja 214 W. Sukiennickiego, sygn. 2, Materiały do życiorysu, list do B. Sukiennickiego z 7 XII 1976; Kolekcja 435 H. Sukiennickiej, sygn. 1, Życiorys i wspomnienia.

Lietuvos centrinis valstybès archyvas w Wilnie, f. 175, op. 1(I)A, spr. 101, Wydział Lekarski; f. 175, op. 1(I)Bb, spr. 63, Teczka personalna J. Wilczyńskiego; f. 175, op. 3(IX)B, spr. 181, 182, 184, Protokoły posiedzeń Rady Wydziału Lekarskiego; f. 175, op. 14, spr. 630, Teczka personalna J. Wilczyńskiego.

Opracowania

Corpus Studiosorum Universitatis Iagellonicae 1850/51-1917/18, t. 3: T-Ż, red. K. Stopka, [aut. M. Barcik i in.], Kraków 2015.

Flin P., Panko E., Stopnie naukowe w carskiej Rosji, „Prace Komisji Historii Nauki PAU” 2015, t. XIV.

Hübner P., Polityka naukowa w Polsce w latach 1944-1953. Geneza systemu, t. I, WrocławWarszawa-Kraków 1992.

Informator o archiwach z kresów pótnocno-wschodnich Drugiej Rzeczypospolitej $w$ zasobie archiwów białoruskich i LCVA w Wilnie, oprac. J. J. Milewski, Białystok 1996.

Jan Z. Wilczyński, „Sprawozdania Towarzystwa Naukowego w Toruniu” 1952, z. 1-4.

Jastrzębski J., Habilitacja w państwowym szkolnictwie akademickim II Rzeczypospolitej, „Analecta. Studia i Materiały z Dziejów Nauki”, R. XIX, 2010, z. 1-2.

Kolankowski L., Pierwsze trzy lata istnienia UMK (1945-1948). Garść wspomnień pierwszego rektora z okresu organizacyjnego, oprac. S. Grochowina, w: Ludwik Kolankowski 18821956. W pięćdziesiąta rocznice śmierci, red. W. Sieradzan, Torun 2006.

Księga Pamiatkowa ku uczczeniu CCCL rocznicy założenia i X wskrzeszenia Uniwersytetu Wileńskiego, t. 1: Z dziejów dawnego Uniwersytetu; t. 2: Dziesięciolecie 1919-1929, Wilno 1929.

Lednicki W., Pamiętniki, t. 1, Toruń 2019.

Pamiętnik Wileński, wyd. 1: Londyn 1972, wyd. 2: Londyn-Lomianki 2010.

Perkowska U., Corpus Academicorum Facultatis Philosophiae Universitatis Iagellonicae 1850 1945, Kraków 2007.

Pracownicy nauki i dydaktyki Uniwersytetu Mikołaja Kopernika 1945-2004. Materiały do biografii, red. S. Kalembka, Toruń 2006.

Przeniosło M., Stopnie, tytuly i stanowiska naukowe w II Rzeczypospolitej, „Res Historica” 2012, z. 33.

Róziewicz J., Zasztowt L., Polskie Kolegium Uniwersyteckie w Kijowie (1917-1919), „Rozprawy z Dziejów Oświaty", 1991, s. 93-123.

Rutkowski T. P., Nauki historyczne w Polsce 1944-1977. Zagadnienia polityczne i organizacyjne, Warszawa 2007.

Staniewicz W., Dwór Wersoka Wielka, Wilno 1926.

Supruniuk A., Supruniuk M. A., Tajemnicze poczatki Uniwersytetu Mikołaja Kopernika (Wilno i Lwów w Toruniu), Toruń 2017. 
Ustawa z 13 VII 1920 r. o szkołach akademickich, DzURP 1920, nr 72, poz. 494.

Wilczyński Jan Zygmunt, [w:] Pro memoria, oprac. Z. Wajda, Pelplin 2009.

Wilczyński J., O dobrych zwyczajach akademickich i potrzebie ich chowania $w$ Polsce, Wilno 1932.

Wojtczak K., O stopniach naukowych i veniam legendi w II Rzeczypospolitej (część I), „Studia Prawa Publicznego" 2014, nr 3.

Zbiór najważniejszych przepisów uniwersyteckich, oprac. K. W. Kumaniecki, Kraków 1913.

Żongołłowicz B., Dzienniki 1930-1936, oprac. D. Zamojska, Warszawa 2004.

Żukowski P. M., Stownik docentów Uniwersytetu Stefana Batorego w Wilnie w latach 1919 1939 (w przygotowaniu).

\section{STEPHEN BATHORY UNIVERSITY IN VILNIUS IN THE YEARS 1929-1939 IN THE RECOLLECTIONS OF JAN WILCZYŃSKI}

The article focuses on the history of Stephen Bathory University in Vilnius (SBU). First, it introduces Jan Zygmunt Wilczyński (1891-1970), who worked as a scientist at SBU in the years 1919-1939, and then at Nicolaus Copernicus University in Torun in the years 1945-1951. The second part focuses on Jan Wilczyński's recollections which refer mostly to the second decade of the history of SBU.

KEY WORDS: Jan Zygmunt Wilczyński, Saint Petersburg University, the Jagiellonian University in Kraków, Polish University College in Kiev, Stephen Bathory University in Vilnius, Nicolaus Copernicus University in Torun, history of science, botany, zoology, Vilnius, history of emigration

SŁOWA KLUCZOWE: Jan Zygmunt Wilczyński, Uniwersytet w Petersburgu, Uniwersytet Jagielloński w Krakowie, Polskie Kolegium Uniwersyteckie w Kijowie, Uniwersytet Stefana Batorego w Wilnie, Uniwersytet Mikołaja Kopernika w Toruniu, historia nauki, botanika, zoologia, Wilno, dzieje emigracji 